Atmos. Chem. Phys., 14, 2399-2417, 2014

www.atmos-chem-phys.net/14/2399/2014/

doi:10.5194/acp-14-2399-2014

(c) Author(s) 2014. CC Attribution 3.0 License.

\title{
An AeroCom assessment of black carbon in Arctic snow and sea ice
}

\author{
C. Jiao ${ }^{1}$, M. G. Flanner ${ }^{1}$, Y. Balkanski' ${ }^{2}$, S. E. Bauer ${ }^{3,4}$, N. Bellouin ${ }^{5, *}$, T. K. Berntsen ${ }^{6}$, H. Bian ${ }^{7}$, K. S. Carslaw ${ }^{8}$,

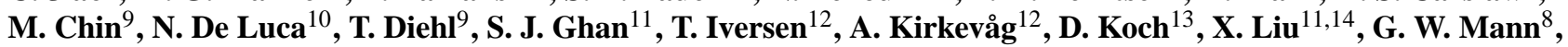 \\ J. E. Penner ${ }^{1}$, G. Pitari ${ }^{10}$, M. Schulz ${ }^{12}$, Ø. Seland ${ }^{12}$, R. B. Skeie ${ }^{15}$, S. D. Steenrod ${ }^{16}$, P. Stier ${ }^{17}$, T. Takemura ${ }^{18}$, \\ K. Tsigaridis ${ }^{3,4}$, T. van Noije ${ }^{19}$, Y. Yun ${ }^{20}$, and K. Zhang ${ }^{11,21}$ \\ ${ }^{1}$ Department of Atmospheric, Oceanic and Space Sciences, University of Michigan, Ann Arbor, MI, USA \\ ${ }^{2}$ Laboratoire des Sciences du Climat et de l'Environnement, CEA-CNRS-UVSQ, Gif-sur-Yvette, France \\ ${ }^{3}$ Center for Climate Systems Research, Columbia University, New York, NY, USA \\ ${ }^{4}$ NASA Goddard Institute for Space Studies, New York, NY, USA \\ ${ }^{5}$ Met Office Hadley Centre, Exeter, UK \\ ${ }^{6}$ Department of Geosciences, University of Oslo, Oslo, Norway \\ ${ }^{7}$ University of Maryland, Baltimore County, MD, USA \\ ${ }^{8}$ Institute for Climate and Atmospheric Science, School of Earth and Environment, University of Leeds, Leeds, UK \\ ${ }^{9}$ NASA Goddard Space Flight Center, Greenbelt, MD, USA \\ ${ }^{10}$ Dipartimento di Scienze Fisiche e Chimiche, Università degli Studi L'Aquila, Coppito, L'Aquila, Italy \\ ${ }^{11}$ Pacific Northwest National Laboratory, Richland, WA, USA \\ ${ }^{12}$ Norwegian Meteorological Institute, Oslo, Norway \\ ${ }^{13}$ Department of Energy, Office of Biological and Environmental Research, USA \\ ${ }^{14}$ Department of Atmospheric Science, University of Wyoming, Laramie, WY, USA \\ ${ }^{15}$ Center for International Climate and Environmental Research-Oslo (CICERO), Oslo, Norway \\ ${ }^{16}$ University Space Research Association, MD, USA \\ ${ }^{17}$ Department of Physics, University of Oxford, Oxford, UK \\ ${ }^{18}$ Research Institute for Applied mechanics, Kyushu University, Fukuoka, Japan \\ ${ }^{19}$ Royal Netherlands Meteorological Institute, De Bilt, the Netherlands \\ ${ }^{20}$ Geophysical Fluid Dynamics Laboratory, NOAA, P.O. Box 308, Princeton, NJ, USA \\ ${ }^{21}$ Max Planck Institute for Meteorology, Hamburg, Germany \\ *now at: Department of Meteorology, University of Reading, Reading, UK
}

Correspondence to: C. Jiao (chaoyij@umich.edu)

Received: 23 August 2013 - Published in Atmos. Chem. Phys. Discuss.: 10 October 2013

Revised: 17 January 2014 - Accepted: 30 January 2014 - Published: 7 March 2014

\begin{abstract}
Though many global aerosols models prognose surface deposition, only a few models have been used to directly simulate the radiative effect from black carbon (BC) deposition to snow and sea ice. Here, we apply aerosol deposition fields from 25 models contributing to two phases of the Aerosol Comparisons between Observations and Models (AeroCom) project to simulate and evaluate within-snow $\mathrm{BC}$ concentrations and radiative effect in the Arctic. We accomplish this by driving the offline land and sea ice components of the Community Earth System Model with different deposition fields and meteorological conditions from
\end{abstract}

2004 to 2009, during which an extensive field campaign of BC measurements in Arctic snow occurred. We find that models generally underestimate BC concentrations in snow in northern Russia and Norway, while overestimating BC amounts elsewhere in the Arctic. Although simulated BC distributions in snow are poorly correlated with measurements, mean values are reasonable. The multi-model mean (range) bias in BC concentrations, sampled over the same grid cells, snow depths, and months of measurements, are $-4.4(-13.2$ to +10.7$) \mathrm{ng} \mathrm{g}^{-1}$ for an earlier phase of AeroCom models (phase I), and $+4.1(-13.0$ to +21.4$) \mathrm{ng} \mathrm{g}^{-1}$ 
for a more recent phase of AeroCom models (phase II), compared to the observational mean of $19.2 \mathrm{ng} \mathrm{g}^{-1}$. Factors determining model $\mathrm{BC}$ concentrations in Arctic snow include Arctic BC emissions, transport of extra-Arctic aerosols, precipitation, deposition efficiency of aerosols within the Arctic, and meltwater removal of particles in snow. Sensitivity studies show that the model-measurement evaluation is only weakly affected by meltwater scavenging efficiency because most measurements were conducted in non-melting snow. The Arctic $\left(60-90^{\circ} \mathrm{N}\right)$ atmospheric residence time for $\mathrm{BC}$ in phase II models ranges from 3.7 to 23.2 days, implying large inter-model variation in local $\mathrm{BC}$ deposition efficiency. Combined with the fact that most Arctic BC deposition originates from extra-Arctic emissions, these results suggest that aerosol removal processes are a leading source of variation in model performance. The multi-model mean (full range) of Arctic radiative effect from $\mathrm{BC}$ in snow is 0.15 $(0.07-0.25) \mathrm{W} \mathrm{m}^{-2}$ and $0.18(0.06-0.28) \mathrm{W} \mathrm{m}^{-2}$ in phase I and phase II models, respectively. After correcting for model biases relative to observed $\mathrm{BC}$ concentrations in different regions of the Arctic, we obtain a multi-model mean Arctic radiative effect of $0.17 \mathrm{~W} \mathrm{~m}^{-2}$ for the combined AeroCom ensembles. Finally, there is a high correlation between modeled BC concentrations sampled over the observational sites and the Arctic as a whole, indicating that the field campaign provided a reasonable sample of the Arctic.

\section{Introduction}

Black carbon (BC) is a light-absorbing carbonaceous component of aerosol originating from the incomplete combustion of biomass and fossil fuel. The amount of $\mathrm{BC}$ emitted into the atmosphere has increased substantially during the industrial era (Bond et al., 2007, 2013). The spatial pattern of BC emissions has also shifted considerably, with North American emissions likely decreasing since the early 20th century (McConnell et al., 2007), European emissions declining after the 1960s, and emissions from Asia increasing during recent decades (e.g., Bond et al., 2007). Global BC emissions from fossil fuel and biofuel combustion have increased by more than a factor of 4 since 1850 .

$\mathrm{BC}$ aerosols can influence climate through different ways, including direct radiative forcing, semi-direct cloud effects, indirect cloud effects, and deposition to snow and ice surfaces (e.g., Menon et al., 2002; Hansen and Nazarenko, 2004; Jacobson, 2004; Stier et al., 2007; Flanner et al., 2009; Koch and Del Genio, 2010; Koch et al., 2011; Bond et al., 2013). During the sunlit seasons, the reduction of snow and ice albedo caused by BC increases surface solar heating and can accelerate melting of the cryosphere. This process triggers albedo feedback in the climate system, leading to higher efficacy than other forcing mechanisms (Hansen and Nazarenko, 2004). The instantaneous increase of solar radiation absorp- tion caused by the presence of $\mathrm{BC}$ in snow and sea ice, termed the BC-in-snow radiative effect, has been estimated by forward modeling with global aerosol and climate models (GCMs), but has uncertainties originating from global BC emissions, atmospheric transport and deposition processes, model snow and ice cover, BC optical properties, snow effective grain size, coincident absorption from other lightabsorbing constituents, and post-depositional transport of BC with meltwater (Flanner et al., 2007; Bond et al., 2013). Flanner et al. (2007) quantified some of these uncertainties using a series of GCM simulations, finding that BC emissions and snow aging (which determines the snow effective grain size) are large sources of uncertainty. They did not, however, examine uncertainty or inter-model variability associated with $\mathrm{BC}$ transport and deposition to snow surfaces, a topic explored in this study.

Measurements of BC in Arctic snow and ice provide an opportunity to evaluate model deposition of $\mathrm{BC}$ at high latitudes and constrain the Arctic BC-in-snow radiative effect (Dou et al., 2012; Lee et al., 2013b). Doherty et al. (2010) report on a comprehensive survey of Arctic BC-in-snow measurements collected 2005-2009. More than 700 snow samples were collected, melted, filtered, and analyzed for $\mathrm{BC}$ mass using the spectral distribution of light absorption through the filter. This publicly available data set, with extensive spatial distribution over the Arctic, provides a useful basis for conducting a multi-model evaluation of Arctic BC deposition.

The Aerosol Comparisons between Observations and Models (AeroCom) project was initiated for the aerosol observation and modeling communities to synthesize results in order to improve aerosol simulation skills (Kinne et al., 2006; Schulz et al., 2006; Textor et al., 2006, 2007; Koffi et al., 2012; Myhre et al., 2013; Samset et al., 2013; Stier et al., 2013). A large number of global aerosol models have contributed to the AeroCom archive. Several studies have used this archive to evaluate model spatial and temporal distributions of aerosol properties (e.g., Textor et al., 2007; Koch et al., 2009; Koffi et al., 2012; Myhre et al., 2013). For example, Koch et al. (2009) evaluated AeroCom models against surface and aircraft measurements of $\mathrm{BC}$ concentrations, aerosol absorption optical depth (AAOD) retrievals, and BC column estimates. They found the largest model diversity in northern Eurasia and the remote Arctic, and showed that most models simulate too little $\mathrm{BC}$ in the springtime lower Arctic atmosphere relative to aircraft measurements, but that models may simulate too much BC in the higher Arctic atmosphere. Schwarz et al. (2010) also find AeroCom models underestimate $\mathrm{BC}$ in the lower Arctic troposphere compared with observations from the HIPPO campaign.

Other studies of large model ensembles have also found important features that are valuable for understanding Arctic pollutant impacts. Shindell et al. (2008) applied 17 models to assess the pollution transport to the Arctic. They found that inter-model variations are large and originate mainly 
from differences in the representations of physical and chemical processes, but that the relative importance of emissions from different regions is robust across models. North America is the major contributor to Arctic ozone and $\mathrm{BC}$ deposited on Greenland, whereas European emissions dominate the total $\mathrm{BC}$ deposition elsewhere in the Arctic. Lee et al. (2013b) evaluated historical BC aerosols simulated by 8 ACCMIP models against observations. They found that year 2000 global atmospheric BC burden varies by about a factor of 3 among models, despite all models applying the same emissions. Modeled BC concentrations in snow and sea ice were generally within a factor of 2-3 of observations, while the seasonal cycle of atmospheric $\mathrm{BC}$ in the Arctic was poorly simulated.

Though all AeroCom models simulate aerosol deposition to the surface, most of them do not simulate vertically resolved concentrations of BC in snow and sea ice, governed, e.g., by meltwater removal, fresh snowfall, and sublimation. The simulation of such distributions is critical for meaningful evaluation of model data against surveys like that of Doherty et al. (2010), which includes measurements of BC at different snow depths and in snow subject to different climate conditions. New capabilities in the Community Land Model (CLM) and Community Ice CodE (CICE) components of the Community Earth System Model (CESM) permit (1) the simulation of vertically resolved $\mathrm{BC}$ concentrations in snow and sea ice, and (2) the use of prescribed aerosol deposition fields, such as those generated from AeroCom models, to drive the offline land and sea ice models. Here, we exploit these capabilities in dozens of CLM and CICE simulations to explore inter-model variabilities in Arctic BC transport and deposition, and evaluate subsequent impacts on Arctic $\mathrm{BC}$-in-snow radiative effects. We also explore the sensitivity of model-measurement comparisons to meltwater removal efficiency, one of the key uncertainties in simulated BC-insnow forcing (Flanner et al., 2007; Bond et al., 2013), and consistency between model meteorology and deposition. We have also applied the framework developed here in recent collaborative efforts to quantify radiative effects from ACCMIP models (Lee et al., 2013b; Shindell et al., 2013).

\section{Observational data}

We used the measurements of $\mathrm{BC}$-in-snow concentration published by Doherty et al. (2010). These measurements were conducted in different sectors of the Arctic during 2005-2009, mostly during March to August. The snow samples were generally collected in locations far from anthropogenic sources (e.g., roads, villages and cities) so they represent regions which are not strongly affected by local pollution. Samples collected near the city of Vorkuta, Russia, have high BC-in-snow concentrations (i.e., $\gg 100 \mathrm{ng} \mathrm{g}^{-1}$ ), however, indicating influence of local pollution, and are also included in our model evaluation.
Doherty et al. (2010) reported three types of BC concentrations from their measurements: maximum $\mathrm{BC}$, estimated $\mathrm{BC}$, and equivalent $\mathrm{BC}$. The estimated $\mathrm{BC}$ is the estimated true mass of black carbon per mass of snow by using the wavelength-dependence of the measured absorption, and the estimated $\mathrm{BC}$ was used for comparison with simulated $\mathrm{BC}$ mass in our study. The mass-absorption cross-section (MAC) of BC assumed in the analysis was $6.0 \mathrm{~m}^{2} \mathrm{~g}^{-1}$ at $550 \mathrm{~nm}$. If actual BC MAC was higher (lower) than that assumed by Doherty et al. (2010), actual BC mass in the snow was lower (higher). The non-BC light-absorbing aerosols are likely dominated by organic carbon (OC) and dust. A more detailed description of the method is provided by Grenfell et al. (2011). Most models do not differentiate aerosol species such as brown carbon, which is generally grouped into the OC category in emission inventories employed by models. The observations include 797 samples in total, and have been grouped into 8 different regions: (1) Arctic Ocean, (2) Canadian Arctic, (3) Alaska, (4) Canadian Sub-Arctic, (5) Greenland, (6) Ny-Ålesund, (7) Tromsø, and (8) Russia. Here we adopt the same partitioning of regions. The locations of these samples are shown in Fig. 2 of Doherty et al. (2010). The campaign includes snow samples collected during five years, but data from most locations have temporal extent of only a few months at most.

\section{Methods}

BC concentrations in land-based snow are simulated with CLM4 (e.g., Lawrence et al., 2011), run at $1.9^{\circ} \times 2.5^{\circ}$ horizontal resolution. To simulate $\mathrm{BC}$ in snow on sea ice, we use the CICE4 model (e.g., Holland et al., 2012). Flanner et al. (2007) and Lawrence et al. (2011) provide descriptions of the treatment of radiative transfer and aerosol processes in land snow, and sea ice treatments are described by Briegleb and Light (2007) and Holland et al. (2012). Briefly, both model components apply two-stream, multilayer, multi-spectral radiative transfer models, and both models simulate changes in vertical aerosol distributions arising from deposition, meltwater flushing, sublimation, and layer combinations and divisions. We drive both models with interannually varying atmospheric reanalysis data with a sixhour time resolution from 2004 to 2009, during which the BC-in-snow measurements were conducted. CLM employs a blended reanalysis from the Climatic Research Unit (CRU) and National Centers for Environmental Prediction (NCEP), described at http://dods.extra.cea.fr/data/p529viov/cruncep/ readme.htm. We drive CICE with NCEP/NCAR reanalysis data (Kistler et al., 1999). Model spin-up occurs during 2004 and the 2005-2009 period is used for the evaluation and analysis of radiative effect. We also conduct a sensitivity study using self-consistent meteorology and aerosol deposition fields at a high temporal resolution (Sect. 4.3). 
We use data from 12 models contributing to the AeroCom phase I intercomparison project (e.g., Kinne et al., 2006; Schulz et al., 2006; Textor et al., 2006, 2007; Koffi et al., 2012) and 13 models contributing to the more recent phase II project (e.g., Myhre et al., 2013; Samset et al., 2013; Stier et al., 2013). Table 1 summarizes the names and descriptions of these models. Each of these models has provided monthly gridded deposition fields of $\mathrm{BC}$, partitioned into wet and dry components. Phase I simulations are conducted under the present-day "B" protocol (Kinne et al., 2006), where all models adopt harmonized BC emissions fields, though possibly with slight differences in the partitioning of emissions in vertical space and size distributions. Phase II simulations are conducted under the present-day "A2 control" protocol (Dentener et al., 2006; Schulz et al., 2009), where each model employs its own emissions, leading to a wider diversity in model deposition fluxes, $\mathrm{BC}$ concentrations in snow, and BC-in-snow radiative effects.

We re-gridded all $\mathrm{BC}$ and dust deposition fields to $1.9^{\circ} \times$ $2.5^{\circ}$ resolution, and used monthly resolved fields to drive the CLM and CICE models. CLM and CICE track vertically resolved hydrophilic and hydrophobic species of $\mathrm{BC}$, from which radiative effect was calculated. We assigned all wet deposition to the hydrophilic species, and partitioned dry deposition into the two species based on monthly, gridded ratios obtained from a CAM4 aerosol simulation. This process resulted in slightly more than half of dry deposition being assigned to the hydrophilic species. One model (UIO-GCM in phase I) did not contribute dust deposition fields to AeroCom. Because dust is also a light absorbing aerosol, the lack of dust contributes to a small positive bias in $\mathrm{BC}$ radiative effect diagnosed for this model, but does not influence the model-observation evaluation.

For each model contribution, we ran CLM and CICE with two sets of $\mathrm{BC}$ meltwater scavenging coefficients. The BC meltwater scavenging coefficient is the ratio of $\mathrm{BC}$ concentration in the meltwater flux leaving a snow layer to the bulk concentration in that snow layer (Flanner et al., 2007). The scenario with inefficient scavenging (IS) applies meltwater scavenging coefficients of 0.2 and 0.03 for hydrophilic and hydrophobic BC, respectively, as used by Flanner et al. (2007) and derived from field measurements (Conway et al., 1996). The efficient scavenging (ES) scenario assumes meltwater scavenging efficiencies of 1.0 for both hydrophilic and hydrophobic $\mathrm{BC}$, meaning each unit of meltwater that passes out of a snow layer carries an amount of BC exactly proportional to the $\mathrm{BC}$ mass concentration in that layer.

Because some samples were collected at the same site or at sites that are very close to each other, multiple measurements taken at similar times and depths can reside within the same grid cell and snow layer(s) represented by the model. This could be problematic for the calculation of mean and median $\mathrm{BC}$ concentrations, since the grid cells containing more observations would receive more weight. Thus, if two or more observations were collected in the same year, month

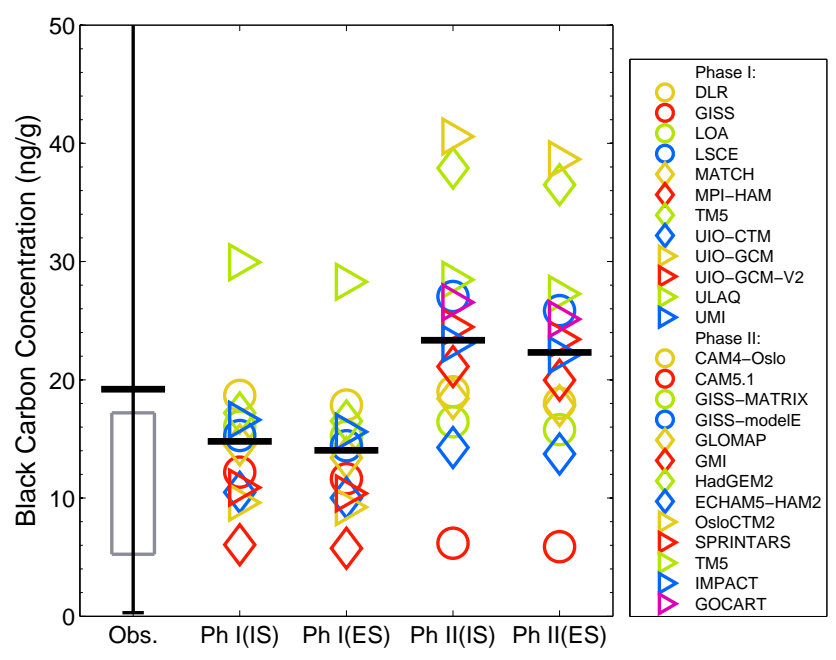

Fig. 1. Observed and modeled black carbon (BC) in snow concentrations in the Arctic. From left to right are observed BC-in-snow concentrations from Doherty et al. (2010), simulated concentrations over the observational domain from AeroCom phase I models with inefficient meltwater scavenging (Ph I(IS)) and efficient scavenging $(\mathrm{Ph} \mathrm{I}(\mathrm{ES}))$, and simulated concentrations from phase II models with inefficient scavenging (Ph II(IS)) and efficient scavenging ( $\mathrm{Ph}$ II(ES)). The gray box indicates the $25 \%$ and $75 \%$ quartiles of the observations, and the whisker depicts the full extent of the observations. Note that the maximum value of $783.5 \mathrm{ng} \mathrm{g}^{-1}$ is outside the figure. The bold horizontal line shows the mean of the observations and models for each scenario. Each colored dot represents the mean of a particular model's simulated BC-in-snow concentration averaged over grid cells matching the location, time, and depth of measurements.

and depth and were within the same grid cell in the model, we first averaged them and then treated them as one for the model comparison. Measurements collected in 1998 for the SHEBA campaign were not used in this exercise. Six measurements aligned with model grid cells that did not have any snow during the month of measurement, and were discarded from the analysis. After the merge and elimination, there were 485 unique observations in 8 regions. The following analysis is based on this merged sample set.

Data from Doherty et al. (2010) include most top and bottom depths from which the snow samples were taken, and we used this information to determine the appropriate model snow layer(s) to compare with. CLM uses up to 5 snow layers, depending on total snow thickness, so we weighted the $\mathrm{BC}$ concentration from each snow layer based on its fractional overlap with the measurement. If the sample only spanned a fraction of the snow layer thickness, we used this fraction multiplied by the snow mass in the layer as the weight for that layer. If the model layer was completely contained within the measurement boundaries, we used the total snow mass as the weight for that layer. Finally, the BC-insnow concentrations from the available layers were averaged by the snow mass weights (normalized to 1) to get the model 
Table 1. Phase I and phase II AeroCom models used in this study.

\begin{tabular}{|c|c|c|c|c|}
\hline Phase & Model name & $\begin{array}{c}\text { Resolution } \\
(\text { lon } \times \text { lat } \times \text { lev })\end{array}$ & $\begin{array}{l}\text { Year of available } \\
\text { deposition field }\end{array}$ & References \\
\hline I & DLR & $96 \times 48 \times 19$ & - & Ackermann et al. (1998) \\
\hline I & GISS & $72 \times 46 \times 20$ & - & Koch et al. (2006); Koch (2001); Bauer and Koch (2005) \\
\hline I & LOA & $96 \times 73 \times 19$ & - & Reddy and Boucher (2004) \\
\hline I & LSCE & $96 \times 73 \times 19$ & - & Szopa et al. (2013) \\
\hline I & MATCH & $192 \times 94 \times 28$ & - & Barth et al. (2000); Rasch et al. $(2000,2001)$ \\
\hline I & MPI-HAM & $192 \times 96 \times 31$ & - & Stier et al. (2005) \\
\hline I & TM5 & $60 \times 45 \times 25$ & - & Krol et al. (2005); de Meij et al. (2006) \\
\hline I & UIO-CTM & $128 \times 64 \times 40$ & - & Grini et al. (2002, 2005); Myhre et al. (2007); Berglen et al. (2004) \\
\hline I & UIO-GCM & $128 \times 64 \times 18$ & - & Iversen and Seland (2002); Kirkevåg and Iversen (2002) \\
\hline I & UIO-GCM-V2 & $128 \times 64 \times 26$ & - & Seland et al. (2008) \\
\hline I & ULAQ & $16 \times 19 \times 26$ & - & Pitari et al. $(2002,2008)$ \\
\hline I & UMI & $144 \times 91 \times 30$ & - & Liu and Penner (2002) \\
\hline II & CAM4-Oslo & $144 \times 96 \times 26$ & 9999* & Kirkevåg et al. (2013) \\
\hline II & CAM5.1 & $144 \times 96 \times 30$ & 2006 & Liu et al. (2012); Ghan et al. (2012) \\
\hline II & GISS-MATRIX & $144 \times 90 \times 40$ & 2006-2008 & Bauer et al. $(2008,2010)$ \\
\hline II & GISS-modelE & $144 \times 90 \times 40$ & 2004-2008 & Koch et al. (2006, 2007); Bauer et al. (2007) \\
\hline II & GLOMAP & $128 \times 64 \times 31$ & 2006 & Spracklen et al. $(2005,2011)$ \\
\hline II & GMI & $144 \times 91 \times 42$ & 2006 & Bian et al. (2009) \\
\hline II & HadGEM2 & $192 \times 145 \times 38$ & 2006-2008 & Bellouin et al. (2011) \\
\hline II & ECHAM5-HAM2 & $192 \times 96 \times 31$ & 2006,2008 & Stier et al. (2005); Zhang et al. (2012) \\
\hline II & OsloCTM2 & $128 \times 64 \times 60$ & 2006 & Myhre et al. (2009); Skeie et al. (2011b, a) \\
\hline II & SPRINTARS & $320 \times 160 \times 56$ & 2006 & Takemura et al. $(2005,2009)$ \\
\hline II & TM5 & $120 \times 90 \times 34$ & 2006 & Vignati et al. (2010); Aan de Brugh et al. (2011); von Hardenberg et al. (2012) \\
\hline II & IMPACT & $144 \times 91 \times 30$ & 9999 & Yun and Penner (2012) \\
\hline II & GOCART & $144 \times 91 \times 30$ & 2006 & Chin et al. (2009) \\
\hline
\end{tabular}

simulated BC concentrations for depths matching the position of the observation. Due to the short spin-up time (1 year), $\mathrm{BC}$ concentrations in the deepest snow layer did not always reach equilibrium, especially in regions of perennial snow cover and low accumulation like Greenland. Thus, we only used the top 4 layers for the comparison. The CICE model applies 2 snow layers overlying 4 sea ice layers. The depth of the surface snow layer changes with the total snow thickness, equaling half of the total thickness when snow depth is less than or equal to $8 \mathrm{~cm}$, and equaling $4 \mathrm{~cm}$ when the total snow depth is greater than $8 \mathrm{~cm}$. For the observations sampled over sea ice, we used the top and bottom depth of the sample to determine which snow layer on sea ice should be compared with. If the sample extended to both layers, we used the averaged $\mathrm{BC}$ concentration from both layers to compare with the observation.

\section{Results and discussion}

\subsection{Comparison of models and observations}

Figure 1 shows BC-in-snow concentrations from models and observations. The spatial and temporal mean observed BC concentration averaged over all samples is $19.2 \mathrm{ng} \mathrm{g}^{-1}$. The $75 \%$ quartile of the observations is close to the mean value due to skewness caused by high BC concentrations in some parts of Russia. Each color symbol in the figure represents the mean $\mathrm{BC}$ concentration of a model simulation averaged over the locations (grid cell and layer) and months matching the observations. With inefficient melt scavenging (IS), the multi-model mean concentration over the observational domain is $14.8 \mathrm{ng} \mathrm{g}^{-1}$ for the twelve phase I simulations and $23.3 \mathrm{ng} \mathrm{g}^{-1}$ for the thirteen phase II models. With efficient scavenging (ES), the phase I and phase II multi-model means are 14.0 and $22.3 \mathrm{ng} \mathrm{g}^{-1}$, respectively. The relatively small decrease associated with ES is discussed further in Sect. 4.4. There is a factor of 5 spread between the highest and lowest phase I model means, and a 6.5 -fold spread among phase II models. The normalized standard deviation of model means is 0.41 and 0.40 for phase I and phase II IS runs, respectively. The inter-model variation in bias is also large for both phase I and phase II models (Table 2).

Three general factors could lead to the large inter-model diversity. Firstly, the transport schemes and meteorology vary between models. A large portion of the aerosol burden in the Arctic is transported from middle and lower latitudes (Koch and Hansen, 2005), amplifying the effects of differences in model transport and removal physics. There are several pathways for pollutant transport to the Arctic, each with seasonality governed by scavenging efficiency and features of the Arctic dome. Stohl (2006) found that Arctic pollution originating from North America and Asia generally experiences uplift outside the Arctic and then a descent into the Arctic. Pollution from Europe travels to the Arctic by 
Table 2. Statistics of the comparison between models and observations. The correlation coefficients and significance levels are calculated by a linear regression fitted to all pairs of observations and corresponding modeled values from the same time and location. Biases are the differences between the mean of modeled values and the mean of observations. The mean observed BC-in-snow concentration is $19.2 \mathrm{ng} \mathrm{g}^{-1}$.

\begin{tabular}{|c|c|c|c|c|c|}
\hline \multirow[t]{2}{*}{ Phase } & \multirow[t]{2}{*}{ Model } & $\begin{array}{l}\text { Correlation } \\
\text { coefficient }\end{array}$ & Bias $\left(\operatorname{ng~g}^{-1}\right)$ & $\begin{array}{l}\text { Correlation } \\
\text { coefficient }\end{array}$ & $\operatorname{Bias}\left(\mathrm{ng} \mathrm{g}^{-1}\right)$ \\
\hline & & \multicolumn{2}{|c|}{ (inefficient scavenging) } & \multicolumn{2}{|c|}{ (efficient scavenging) } \\
\hline I & DLR & $0.21^{*}$ & -0.5 & $0.20^{*}$ & -1.3 \\
\hline I & GISS & $0.15^{*}$ & -7.0 & $0.14^{*}$ & -7.6 \\
\hline I & LOA & $0.15^{*}$ & -3.1 & $0.14^{*}$ & -4.0 \\
\hline I & LSCE & $0.16^{*}$ & -3.9 & $0.15^{*}$ & -4.8 \\
\hline I & MATCH & $0.11^{*}$ & -4.7 & $0.12^{*}$ & -5.8 \\
\hline I & MPI-HAM & $0.22^{*}$ & -13.2 & $0.21^{*}$ & -13.4 \\
\hline I & TM5 & $0.28^{*}$ & -2.0 & $0.27^{*}$ & -2.7 \\
\hline I & UIO-CTM & $0.28^{*}$ & -8.7 & $0.27^{*}$ & -9.2 \\
\hline I & UIO-GCM & $0.15^{*}$ & -9.6 & $0.14^{*}$ & -10.0 \\
\hline I & UIO-GCM-V2 & $0.14^{*}$ & -8.3 & $0.13^{*}$ & -8.8 \\
\hline I & ULAQ & $0.14^{*}$ & +10.7 & $0.14^{*}$ & +9.1 \\
\hline I & UMI & $0.21^{*}$ & -2.6 & $0.21^{*}$ & -3.6 \\
\hline \multicolumn{2}{|c|}{ Phase I mean } & - & -4.4 & - & -5.2 \\
\hline II & CAM4-Oslo & $0.12^{*}$ & -0.2 & $0.12^{*}$ & -1.2 \\
\hline II & CAM5.1 & $0.23^{*}$ & -13.0 & $0.22^{*}$ & -13.3 \\
\hline II & GISS-MATRIX & $0.21^{*}$ & -2.8 & $0.21^{*}$ & -3.4 \\
\hline II & GISS-modelE & $0.21^{*}$ & +7.8 & $0.20^{*}$ & +6.7 \\
\hline II & GLOMAP & 0.05 & -0.8 & 0.04 & -1.4 \\
\hline II & GMI & $0.10^{*}$ & +1.9 & $0.10^{*}$ & +0.8 \\
\hline II & HadGEM2 & $0.18^{*}$ & +18.7 & $0.18^{*}$ & +17.3 \\
\hline II & ECHAM5-HAM2 & $0.18^{*}$ & -4.9 & $0.17^{*}$ & -5.5 \\
\hline II & OsloCTM2 & $0.10^{*}$ & +21.4 & $0.09 *$ & +19.5 \\
\hline II & SPRINTARS & 0.06 & +5.3 & 0.06 & +4.2 \\
\hline II & TM5 & $0.14^{*}$ & +9.3 & $0.14^{*}$ & +8.1 \\
\hline II & IMPACT & $0.18^{*}$ & +3.8 & $0.17^{*}$ & +2.9 \\
\hline II & GOCART & 0.04 & +7.3 & 0.03 & +5.9 \\
\hline \multicolumn{2}{|c|}{ Phase II mean } & - & +4.1 & - & +3.1 \\
\hline
\end{tabular}

* Indicates the regression is significant at $\alpha=0.05$ level.

low-level transport followed by ascent into the Arctic or lowlevel transport alone. Secondly, the characteristics of aerosol deposition processes vary considerably between models. Deposition fluxes are influenced by dry and wet removal representations, model precipitation, aerosol aging and mixing, and aerosol-cloud interactions. Among phase I models, the normalized standard deviation for Arctic BC deposition flux is 0.22 while for phase II models it is 0.27 , indicating larger inter-model diversity for phase II contributions. Some of the increased spread in phase II BC deposition originates from use of different emission inventories, the third factor contributing to inter-model diversity.

Scatter plots shown in Figs. 2 and 3 compare simulated and observed $\mathrm{BC}$ concentrations in different regions. In general, observations and models are more likely to agree with each other in the Arctic Ocean and Ny-Ålesund. Models tend to overestimate $\mathrm{BC}$-in-snow concentrations in the cat- egories of Canadian Arctic, Alaska, Canadian Sub-Arctic and Greenland. In the Canadian Arctic, Canadian Sub-Arctic and Greenland, the means of phase I models are generally within a factor of 3 higher than the means of the observations, while the means of phase II models are about a factor of 3-4 higher. In those three regions, the biases are positive for most of the models, although several models simulate BC concentrations relatively close to the observations. In Alaska, the model-observation disagreement is more substantial. The mean observed $\mathrm{BC}$ concentration in this region is about $12 \mathrm{ng} \mathrm{g}^{-1}$, while the highest value among all models is nearly $170 \mathrm{ng} \mathrm{g}^{-1}$, and the mean phase I and phase II concentrations are $50 \mathrm{ng} \mathrm{g}^{-1}$ and $90 \mathrm{ng} \mathrm{g}^{-1}$, respectively. These model values are higher than those of other regions (Figs. 2 and 3). Importantly, however, there are only 3 measurement samples in the Alaska region, all showing less than $20 \mathrm{ng} \mathrm{g}^{-1}$, potentially biasing the evaluation for this region. The multi-model 
Table 3. Annual mean BC emission and deposition fluxes for the globe and Arctic $\left(60^{\circ} \mathrm{N}\right.$ to $\left.90^{\circ} \mathrm{N}\right)$.

\begin{tabular}{llrrr}
\hline Phase & Model & $\begin{array}{r}\text { Global emission } \\
\text { rate }\left(\mathrm{Tg} \mathrm{yr}^{-1}\right)\end{array}$ & $\begin{array}{r}\text { Arctic emission } \\
\text { rate }\left(10^{7} \mathrm{~kg} \mathrm{yr}^{-1}\right)\end{array}$ & $\begin{array}{r}\text { Arctic deposition } \\
\text { rate }\left(10^{7} \mathrm{~kg} \mathrm{yr}^{-1}\right)\end{array}$ \\
\hline I & DLR & 7.77 & 6.93 & 22.04 \\
I & GISS & $*$ & $*$ & 10.84 \\
I & LOA & $*$ & $*$ & 22.47 \\
I & LSCE & $*$ & $*$ & 20.22 \\
I & MATCH & $*$ & $*$ & 21.19 \\
I & MPI-HAM & $*$ & $*$ & 14.07 \\
I & TM5 & $*$ & $*$ & 19.95 \\
I & UIO-CTM & $*$ & $*$ & 18.27 \\
I & UIO-GCM & $*$ & $*$ & 13.88 \\
I & UIO-GCM-V2 & $*$ & $*$ & 14.95 \\
I & ULAQ & $*$ & $*$ & 22.65 \\
I & UMI & 10.62 & 5.61 & 20.29 \\
II & CAM4-Oslo & 7.76 & 5.64 & 21.45 \\
II & CAM5.1 & 7.58 & 7.67 & 13.19 \\
II & GISS-MATRIX & 7.59 & 7.68 & 22.05 \\
II & GISS-modelE & 8.13 & 4.34 & 19.46 \\
II & GLOMAP & 7.76 & 5.86 & 20.04 \\
II & GMI & 6.63 & 6.33 & 34.45 \\
II & HadGEM2 & 8.11 & 4.05 & 19.49 \\
II & ECHAM5-HAM2 & 7.80 & 6.77 & 28.19 \\
II & OsloCTM2 & 8.12 & 3.71 & 22.45 \\
II & SPRINTARS & 8.22 & 5.78 & 25.54 \\
II & TM5 & 10.55 & 3.94 & 16.13 \\
II & IMPACT & 10.34 & 5.76 & \\
II & GOCART & & & $* 83$ \\
\hline
\end{tabular}

* The total amounts of BC emission are the same for phase I models.

mean concentration of BC in surface snow, averaged annually over all of Alaska, is $41 \mathrm{ng} \mathrm{g}^{-1}$, smaller than averages over the Alaskan sampling domain. In Troms $\varnothing$ and Russia, models tend to underestimate BC-in-snow concentrations over the observational domain. The mean for phase I models is around half the observational mean. The phase II mean is closer to the observations, though these models show more inter-model diversity in these regions than phase I models. One potential factor that could contribute to the underestimation of BC-in-snow concentration in Russia is the omission of high-latitude flaring source in the AeroCom emission inventories (Stohl et al., 2013).

From Figs. 2 and 3, we see that the models capture some spatial characteristics of the observed BC-in-snow concentrations, though correlations between the observations and models are weak. This indicates that the current stage of global aerosol models has difficulty in reproducing the observed distribution of BC in Arctic snow, caused by some combination of biased emission inventories, atmospheric and/or snow aerosol parametrizations, or inconsistent meteorology from that which prevailed during the measurement campaign. Table 2 shows the correlation coefficient $(R)$, statistical significance (i.e., $p$ value smaller than 0.05 ), and bias between the models and observations. The correlation co- efficients are generally small, ranging from 0.11 to 0.28 in phase I IS simulations and 0.12 to 0.27 in ES simulations. In phase II, the correlation coefficients range from 0.04 to 0.23 and 0.03 to 0.22 , respectively, in IS and ES simulations. Despite poor correlation coefficients, mean model biases are reasonably small. Phase I models generally slightly underestimate observed Arctic BC-in-snow concentrations (Table 2). This is consistent with results from Koch et al. (2009), showing that most AeroCom phase I models underestimate the atmospheric concentration of BC compared with observations in the remote Arctic, and also with Shindell et al. (2008), who showed that HTAP models also generally underestimate near-surface measurements of BC at the Arctic Alaska locations Barrow and Alert. Five of the phase II models are biased low while the other eight overestimate BCin-snow concentrations. With inefficient scavenging, the biases range from $-13.2 \mathrm{ng} \mathrm{g}^{-1}$ to $+10.7 \mathrm{ng} \mathrm{g}^{-1}$ for phase I models. For phase II, the lowest and highest mean biases are $-13.0 \mathrm{ng} \mathrm{g}^{-1}$ and $+21.4 \mathrm{ng} \mathrm{g}^{-1}$.

We have so far reported results for both inefficient (IS) and efficient (ES) melt scavenging parameters. The IS parameters are derived from a very limited set of observations, while the ES studies are idealized and designed to test the sensitivity of results to this parameter. Although there is large 

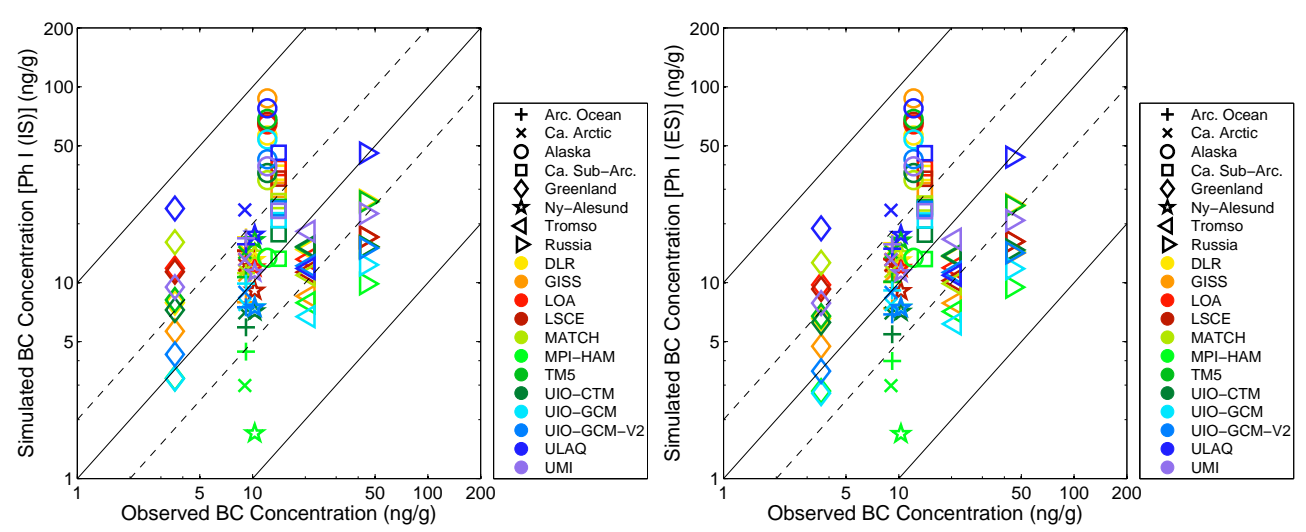

Fig. 2. Log-scale scatter plot of BC-in-snow concentrations simulated in different regions with phase I models applying inefficient meltwater scavenging (left panel) and efficient scavenging (right panel), compared with observations. The mean values for each region are averaged over grid cells matching the location, time, and depth of measurements.
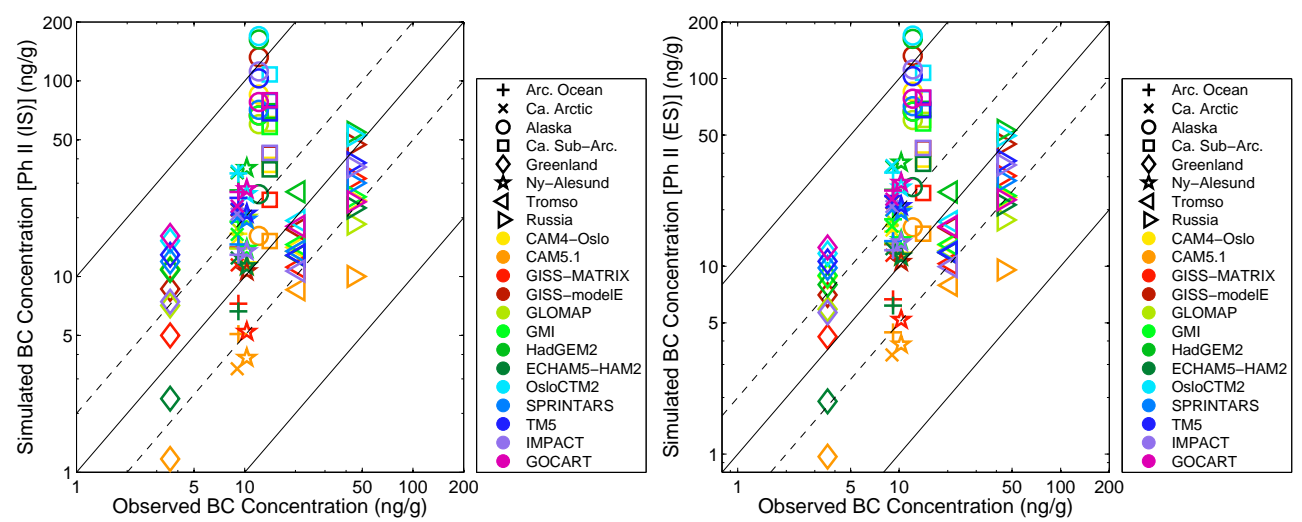

Fig. 3. Same as Fig. 2, but for phase II models.

uncertainty in melt scavenging efficiency, a growing number of observational studies indicate that BC is scavenged inefficiently with melt water (Xu et al., 2012; Doherty et al., 2013; Sterle et al., 2013). From field measurements, Doherty et al. (2013) derived BC meltwater scavenging efficiencies ranging from $10 \%$ to $30 \%$, broadly consistent with the parameters used by Flanner et al. (2007). We also find that 16 of $25 \mathrm{Ae}-$ roCom simulations produce a higher correlation coefficient with IS than ES (though the mean improvement is only 0.01). Consequently, the analysis that follows focuses on IS simulations, except for a sensitivity analysis of melt scavenging in Sect. 4.4.

The observations cover a large area of the Arctic but are relatively sparse in some sectors. Also, the measurements were conducted only during spring and summer, the seasons of most relevance for radiative effects. Thus, the question arises of how well the sampling domain represents the Arctic-mean distribution of BC in surface snow. Figure 4a shows, for each model, the annual mean BC concentration in the surface snow layer averaged over the whole Arctic plotted against the annual mean surface-layer BC concentration averaged spatially and temporally over the model domain matching observations. There is a strong linear relationship between these two quantities. The $R^{2}$ of the linear fit is 0.73 and statistically significant at the 0.001 level. Figure $4 \mathrm{~b}$ plots $\mathrm{BC}$ concentrations weighted by the surface incident solar radiation (ISR) and averaged over the whole Arctic against the same quantity on the $x$ axis as Fig. 4a. This metric places a stronger weight on polluted snow exposed to intense sunlight, which exerts a stronger radiative effect than the same snow surface in polar darkness. It thus gives a better indication of how representative the measurement survey is of the Arctic BC-in-snow radiative effect. The linear relationship in Fig. 4b is stronger, with a $R^{2}$ value of 0.80 . This result suggests that the sampling domain surveyed by Doherty et al. (2010), conducted during seasons of relatively strong insolation, could provide a reasonable constraint on Arctic-wide annual-mean radiative effects from $\mathrm{BC}$-in-snow. The correlation between annual-mean $\mathrm{BC}$ concentrations at each of the measurement sites (a proxy for a scenario with year-round sampling) and Arctic-mean BC-in-snow concentrations is very high $\left(R^{2}=0.95\right.$; not shown $)$. 

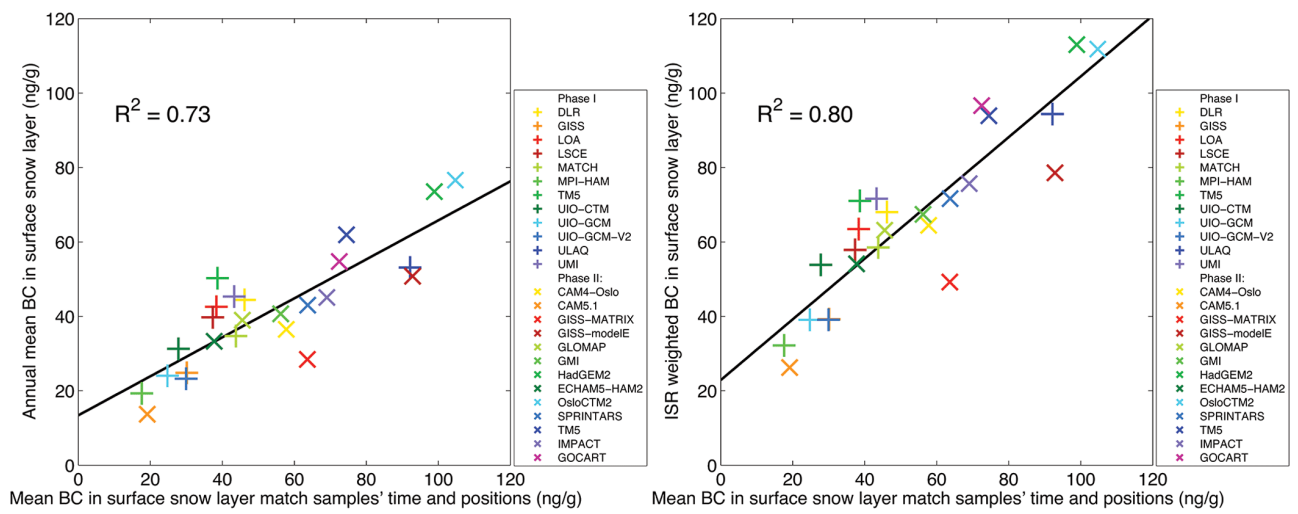

Fig. 4. Relationships between simulated BC-in-snow concentrations averaged over the locations and months of observations and over the whole Arctic region. The abscissa is the surface layer BC-in-snow concentration averaged over grid cells matching the location and time of measurements. The ordinate is the annual mean surface layer BC-in-snow concentration averaged over the whole Arctic region $\left(60^{\circ} \mathrm{N}\right.$ to $90^{\circ}$ N) (left panel: Fig. 4a), and averaged over the Arctic with insolation weighting (right panel: Fig. 4b).
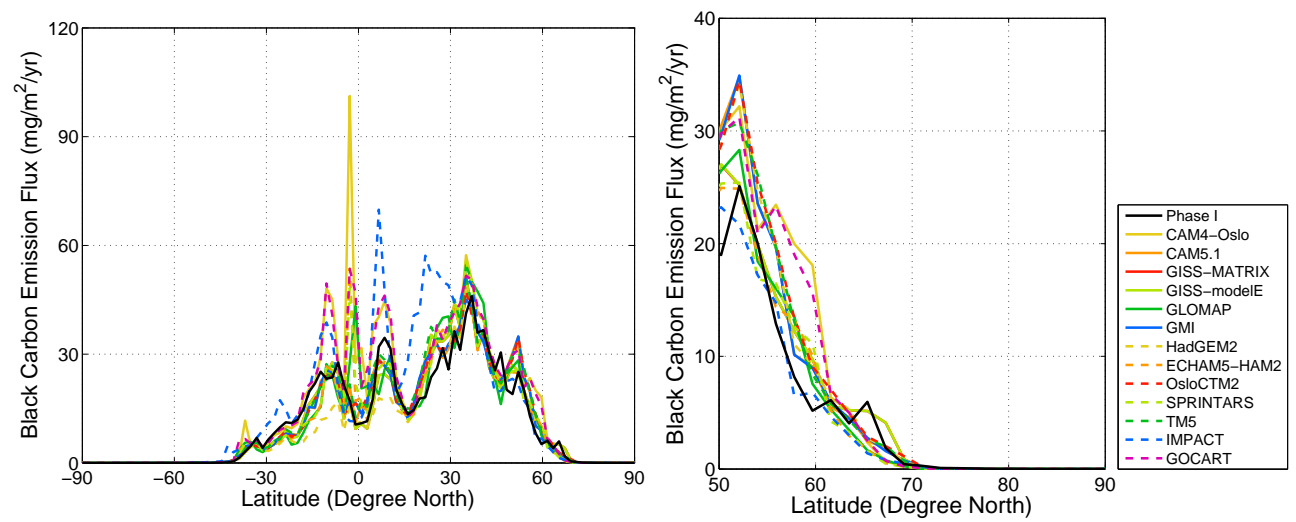

Fig. 5. Annual, zonal-mean black carbon emission fluxes applied in phase I and phase II models for the global (left panel: Fig. 5a) and in more detail in the northern latitude (right panel: Fig. 5b) regions.

\subsection{Emissions}

Phase I models apply the same emission inventory, while phase II models use different inventories. Figure 5 shows the zonal-mean emissions used in each model, plotted globally and for the northern high latitudes. From Fig. 5 we see that phase II models show substantial variations in emissions, especially in the tropics, where biomass burning emissions are large and more variable between inventories. The peak emission fluxes are mostly within $30-40^{\circ} \mathrm{N}$, which includes major populated industrial regions (East Asia, South Asia, parts of North America and Europe). Figure 5b shows that the intermodel variation in $\mathrm{BC}$ emissions at high latitudes is relatively small, and that emissions north of $70^{\circ} \mathrm{N}$ are negligible in the inventories applied.

To identify the importance of inter-model variability in local emissions, we regress annual mean Arctic $\left(60-90^{\circ} \mathrm{N}\right)$ surface BC-in-snow concentrations against annual-mean emission fluxes, but find insignificant correlations both with the fluxes averaged over the Arctic $\left(60-90^{\circ} \mathrm{N}\right)\left(R^{2}=0.03, p=\right.$
$0.55)$ and with emission fluxes averaged in a larger region $\left(50-90^{\circ} \mathrm{N}\right)\left(R^{2}=0.09, p=0.29\right)$. Among phase II models, the ratio between annual mean Arctic deposition and Arctic emission ranges from 2.1 to 6.1, with 10 models having a ratio larger than 3. For phase I models, the ratio ranges from 1.6 to 3.3. This proves, as expected, that most of the model $\mathrm{BC}$ depositing in the Arctic originates from emissions outside the Arctic. The large range of this ratio reveals potential large inter-model vertical variability in aerosol scavenging efficiency as well as in transport efficiency to the Arctic. Variability in mid- and low-latitude emissions contributes to some of the diversity in Arctic deposition of phase II models, but is entwined with the effects of variation in model transport and scavenging mechanisms.

\subsection{Inter-model deposition variability}

Inter-model variability in $\mathrm{BC}$ deposition, the primary direct driver of variation in $\mathrm{BC}$-in-snow concentrations, originates from different emissions and model physics. Figure 6 shows 

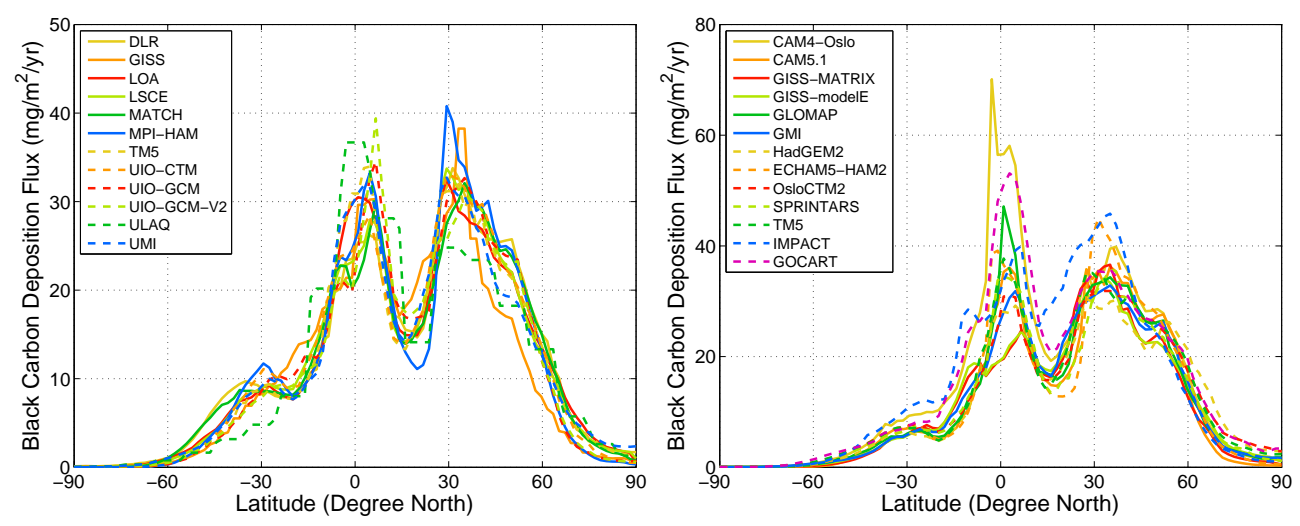

Fig. 6. Annual, zonal-mean black carbon deposition fluxes for phase I (left panel) and phase II (right panel) models. (Note the scale on ordinate is different for the two plots.)

annual zonal-mean BC deposition for phase I (left panel) and phase II (right panel) models, and indicates that the intermodel variation is generally larger in phase II models, including at northern high latitudes. The peak deposition fluxes are near the Equator and $30-40^{\circ} \mathrm{N}$, owing to large emissions sources at these latitudes and efficient removal from ITCZ and monsoon precipitation. Spatial distributions of annual mean $\mathrm{BC}$ deposition over $50-90^{\circ} \mathrm{N}$ are shown in Figs. 7 and 8. These figures show similar patterns among the models, with relatively large deposition over Northern Europe, North America and East Asia, and small deposition over Greenland and the Arctic Ocean. Though the spatial patterns are consistent among these models, the relative magnitudes are different. The phase II HadGEM2 and OsloCTM2 models, in particular, show large BC deposition fluxes in the Arctic. The strong linear relationship $\left(R^{2}=0.80, p<0.001\right)$ between BC deposition fluxes averaged over $60-90^{\circ} \mathrm{N}$ and surface layer BC-in-snow concentration averaged over the same region demonstrates the first-order importance of regional deposition fluxes.

The normalized standard deviation of Arctic deposition is 0.22 for phase I and 0.27 for phase II models. While there is no inter-model variation of emissions (in terms of total emitted mass) for phase I models, the normalized standard deviation of phase II Arctic emissions is 0.23 (Table 3). Together, these results imply that aerosol transport, evolution, and removal processes (combined) are more important contributors to inter-model variation in Arctic BC deposition than emissions. This is also consistent with previous AeroCom analyses showing large variability in model aerosol burdens with harmonized emissions (Textor et al., 2007).

The seasonal cycle of $\mathrm{BC}$ deposition can be important for Arctic BC-in-snow radiative effects. Forcing only occurs during the sunlit period, but $\mathrm{BC}$ deposited during winter can become exposed at the surface during spring and summer melt. Figure 9 shows the monthly mean BC deposition fluxes averaged over $60-90^{\circ} \mathrm{N}$ for phase I and phase II models. The Arctic BC deposition fluxes are relatively low during winter,

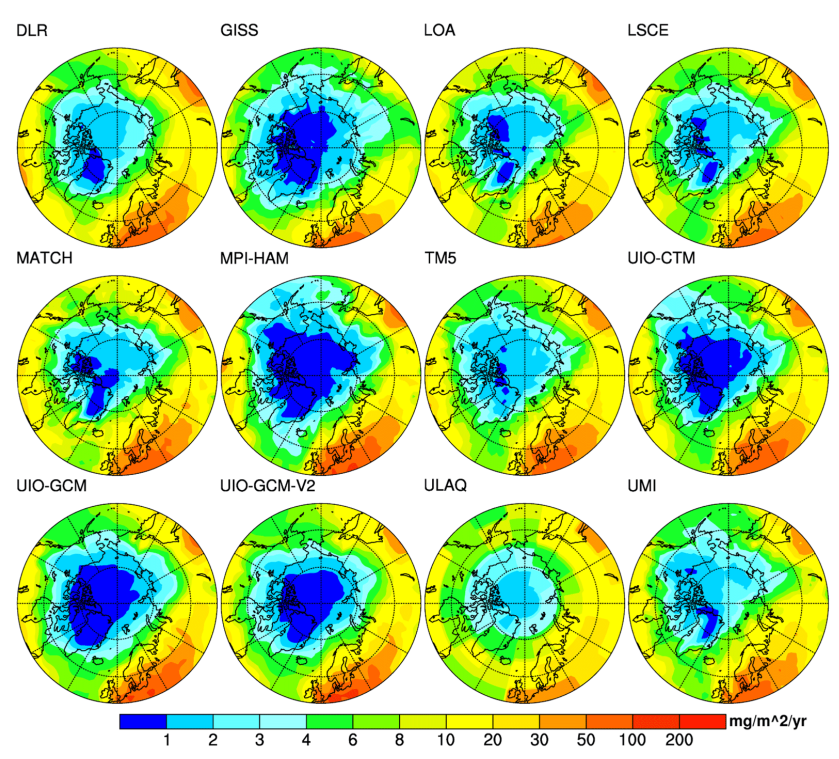

Fig. 7. Annual mean black carbon deposition fluxes for phase I models, plotted from $50^{\circ} \mathrm{N}$ to $90^{\circ} \mathrm{N}$.

when precipitation rates are low and the atmosphere is stably stratified. Deposition starts to increase after March and models generally show a sharp peak between June and August. Among phase I models, one shows Arctic BC deposition peaks in June, seven peak in July, and four in August. Among phase II models, one peaks in May, nine peak in July, one in August and two in September. The seasonal cycles of deposition among phase I models are broadly similar. Most phase II models follow similar seasonal patterns as phase I, though some models peak later. For some models, the contrast between summer and winter is high, while for others it is not. For example, the Arctic deposition flux in July is at least a factor of 3 higher than that in the lowest month for phase II CAM4-Oslo and HadGEM2 models, while seasonal variation is very small in the GMI and IMPACT models. This 


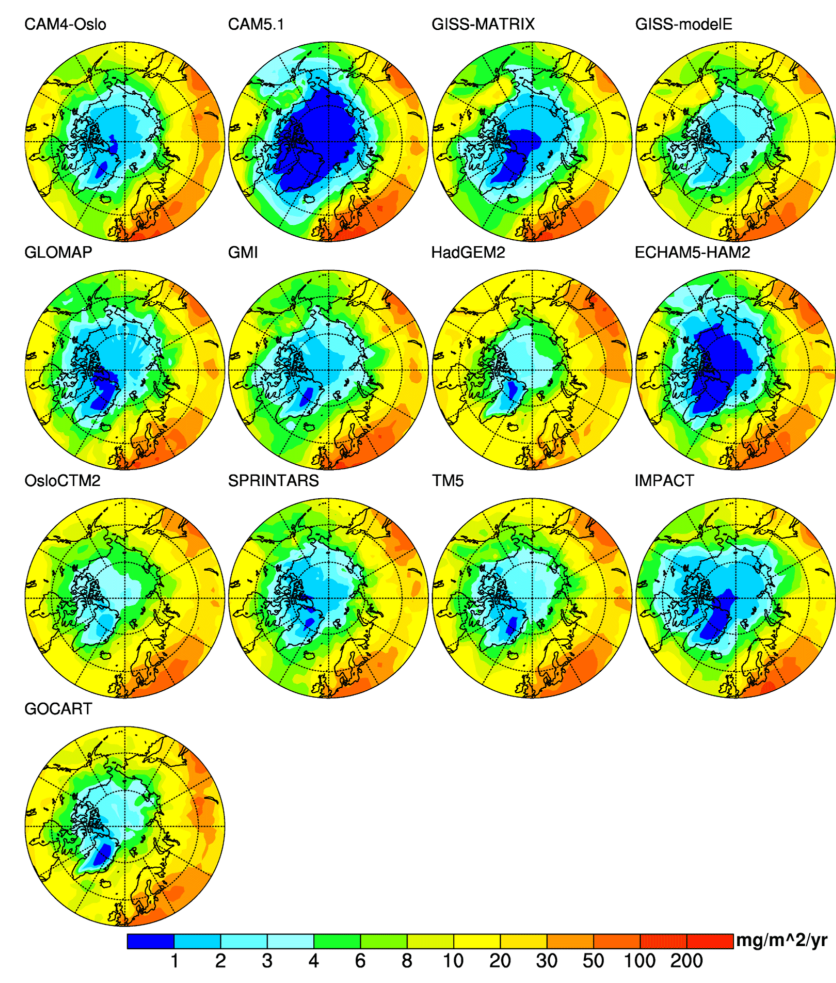

Fig. 8. Annual mean black carbon deposition fluxes for phase II models, plotted from $50^{\circ} \mathrm{N}$ to $90^{\circ} \mathrm{N}$.

diversity originates both from different emission inventories and different chemical and physical parametrizations. Most AeroCom models do not have seasonality for fossil fuel and biofuel emissions. In reality, however, high-latitude biofuel and fossil fuel emission sources tend to be stronger in winter, indicating a potential bias in seasonality of deposition fluxes simulated with seasonally constant emission inventories.

Dividing the Arctic BC column burden by the Arctic deposition flux provides a proxy for Arctic BC residence time. This is imperfect because BC passing through the Arctic atmosphere will contribute to mean burden but not deposition. Nonetheless, the averages are taken over a sufficiently large area so that they should approximate actual Arctic residence time. Here, for simplification, we will call this term "Arctic residence time" despite its potential bias. The Arctic residence time is an indicator of how effectively BC in the Arctic atmosphere deposits through wet and dry processes. Textor et al. (2006) reported that global BC atmospheric residence times for phase I models ranges from 5.2 to 15.0 days. Figure 10 shows the global and Arctic atmospheric residence times of $\mathrm{BC}$ in phase II models. The global $\mathrm{BC}$ residence time ranges from 3.9 to 11.9 days while the Arctic residence time ranges from 3.7 to 23.2 days. The Arctic residence time is longer on average by 4.0 days (median of 2.5 days) than the global residence time, although three models show shorter Arctic than global residence times. Causes for high Arctic residence times include low precipitation rates (especially during polar winter), stable stratification that limits dry turbulent deposition, and long residence time of air parcels that become trapped within the polar dome. Koch et al. (2009) evaluated Arctic atmospheric BC in AeroCom phase I models and found that increasing BC lifetime, which is accomplished by decreasing the aging rate or by reducing removal by ice clouds, has a large impact on BC surface concentrations in remote regions. Analysis of surface measurements at Barrow, Alaska, indicates that the seasonal cycle of "Arctic haze" is dominated by wet scavenging rather than efficiency of transport pathways from source regions (Garrett et al., 2010; Browse et al., 2012; Lund and Berntsen, 2012; Wang et al., 2013). Liu et al. (2011) concluded that the simulation of $\mathrm{BC}$ in the Arctic is significantly improved by using a parameterization of $\mathrm{BC}$ aging rate that is proportional to the $\mathrm{OH}$ radical concentration, reducing dry deposition velocities over ice and snow, and decreasing ice cloud wet removal efficiency. These changes increased wintertime BC concentrations by a factor of 50-100. Browse et al. (2012) improved the simulated seasonal cycle of Arctic aerosols by including more realistic treatment of the transition in scavenging efficiency associated with changes in cloud phases. von Hardenberg et al. (2012) reported a more realistic yearly averaged simulated AOD in the Arctic compared to observations by using the modified wet scavenging scheme suggested by Bourgeois and Bey (2011). Together, these studies indicate that deposition parametrizations are critical for determining both the latitudinal profile of the modeled BC and the efficiency through which Arctic atmospheric BC is removed. Precise attribution of how physical parameterizations contribute to model diversity requires carefully designed perturbation experiments, such as those conducted by Lee et al. (2013a).

One consequence of our methodology for simulating BCin-snow concentrations is that the meteorological conditions used to drive CLM and CICE may be inconsistent with those determining the model deposition amounts. We chose to drive each simulation with the same 2005-2009 reanalysis data because (1) these meteorological conditions are likely to be more compatible than model-generated fields with conditions that prevailed during the measurement campaigns, and thus will produce more similar model snowpack conditions to those from which measurements were drawn, and (2) using the same meteorological conditions for each simulation reduces the number of free variables and enables a more lucid intercomparison of $\mathrm{BC}$-in-snow concentrations resulting from different $\mathrm{BC}$ deposition fields. To evaluate the potential impact of this design choice, we conducted a sensitivity study with CLM and CICE coupled interactively (online) with the Community Atmosphere Model (CAM), and the transport and deposition of aerosols simulated prognostically in a selfconsistent way with model meteorology. We then used deposition fields from this simulation to drive CLM and CICE offline in the same period, using the same reanalysis product as described in Sect. 3. We found that the model-measurement bias averaged over the sampling domain is $-9.7 \mathrm{ng} \mathrm{g}^{-1}$ in 

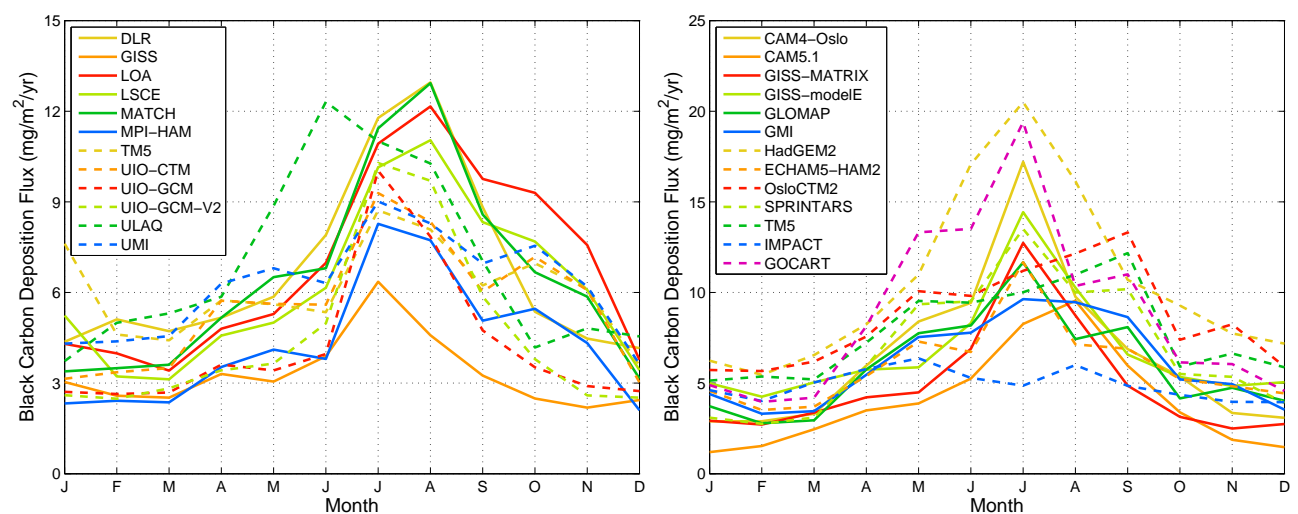

Fig. 9. Seasonal cycle of black carbon deposition fluxes averaged over the Arctic $\left(60^{\circ} \mathrm{N}\right.$ to $\left.90^{\circ} \mathrm{N}\right)$ for phase I (left panel) and phase II (right panel) models. (Note the scale on ordinate is different for the two plots.)

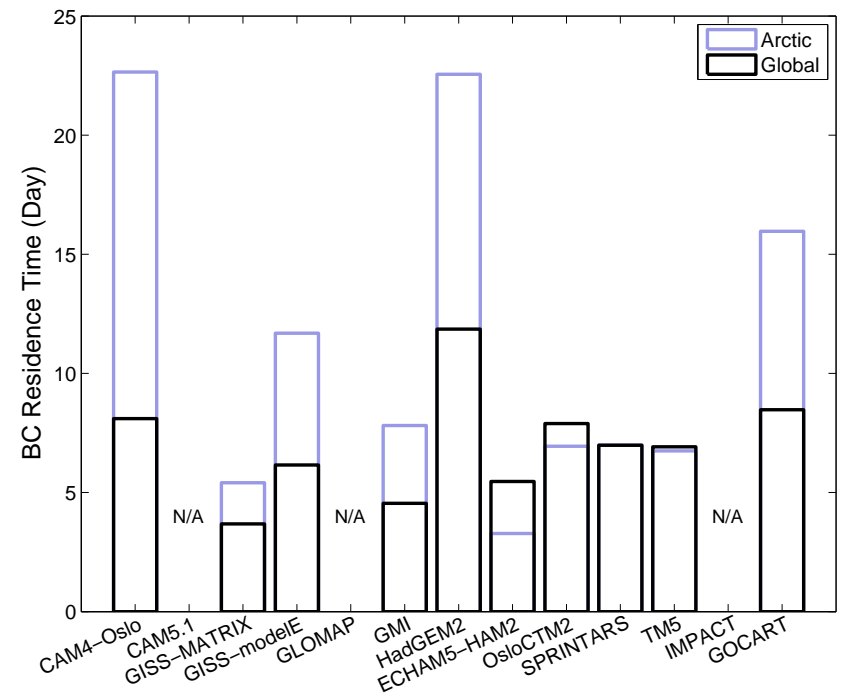

Fig. 10. Global and Arctic atmospheric residence times for black carbon in phase II models. (Three models are excluded in this analysis due to missing or incomplete data.)

the online simulation, while it is $-0.1 \mathrm{ng} \mathrm{g}^{-1}$ for the offline CLM/CICE simulation. The correlation coefficient between model and observation is 0.16 for online simulation and 0.18 for offline simulation. This sensitivity study indicates that choice of meteorology can have a significant impact on model-measurement comparison. The sign of impact is also consistent with a preliminary study (Sarah Doherty, personal communication, 2013), suggesting that use of inconsistent deposition and precipitation fluxes can produce a high bias in surface layer BC concentrations. This could imply that model deposition fluxes in the Arctic have more low bias (or less high bias) than indicated by our study. Applying identical meteorological fields with all deposition fields also likely reduces inter-model diversity in simulated BC-in-snow amounts.
Table 4. Arctic BC-in-snow radiative effects, averaged from $60^{\circ} \mathrm{N}$ to $90^{\circ} \mathrm{N}\left(\mathrm{W} \mathrm{m}^{-2}\right)$.

\begin{tabular}{lcc|lcc}
\hline Phase I & IS $^{\mathrm{a}}$ & ES $^{\mathrm{b}}$ & Phase II & IS $^{\mathrm{a}}$ & ES $^{\mathrm{b}}$ \\
\hline DLR & 0.18 & 0.15 & CAM4-Oslo & 0.16 & 0.13 \\
GISS & 0.10 & 0.09 & CAM5.1 & 0.06 & 0.05 \\
LOA & 0.17 & 0.14 & GISS-MATRIX & 0.12 & 0.10 \\
LSCE & 0.15 & 0.13 & GISS-modelE & 0.20 & 0.17 \\
MATCH & 0.14 & 0.12 & GLOMAP & 0.16 & 0.14 \\
MPI-HAM & 0.07 & 0.06 & GMI & 0.15 & 0.13 \\
TM5 & 0.19 & 0.16 & HadGEM2 & 0.28 & 0.24 \\
UIO-CTM & 0.13 & 0.11 & ECHAM5-HAM2 & 0.11 & 0.09 \\
UIO-GCM & 0.10 & 0.08 & OsloCTM2 & 0.27 & 0.23 \\
UIO-GCM-V2 & 0.10 & 0.08 & SPRINTARS & 0.18 & 0.15 \\
ULAQ & 0.25 & 0.21 & TM5 & 0.23 & 0.20 \\
UMI & 0.18 & 0.15 & IMPACT & 0.17 & 0.15 \\
& & & GOCART & 0.22 & 0.18 \\
\hline
\end{tabular}

${ }^{a}$ IS indicates inefficient meltwater scavenging.

${ }^{\mathrm{b}}$ ES indicates efficient meltwater scavenging.

\subsection{The effect of meltwater scavenging}

As insolation increases during spring in the Arctic, surface snow begins to melt. As the meltwater percolates into deeper snow, it collects some of the impurities, altering the vertical distribution of BC in snow and sea ice. We ran CLM and CICE with two sets of BC meltwater scavenging coefficients in order to evaluate impacts of uncertainty in these parameters. The inefficient scavenging (IS) scenario applies the same scavenging coefficients used by Flanner et al. (2007), leading to accumulation of $\mathrm{BC}$ near the snow surface as melt occurs, whereas the ES sensitivity studies apply scavenging coefficients of 1.0 for both hydrophilic and hydrophobic BC. Though the ES scenario is not supported with observations, it enables an assessment of the potential impact of this parameter on the model evaluations.

Figure 11 divides the model-measurement comparison shown in Fig. 1 into eight different regions. From Fig. 11, we can see that the scavenging sensitivity study has different 

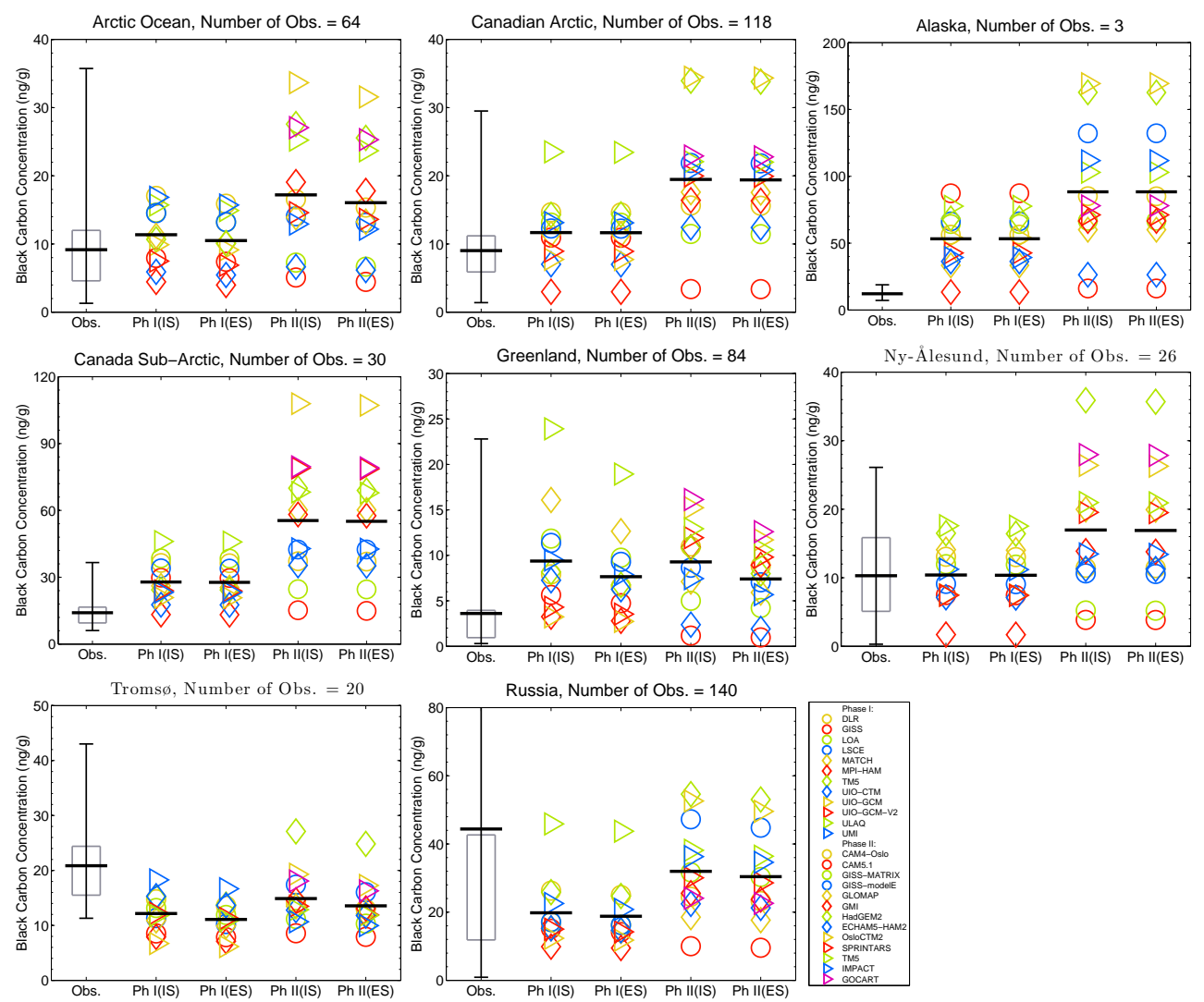

Fig. 11. Same as Fig. 1, but plotted for 8 individual regions. The number of observations within each region is listed in the figure titles.

impacts in different regions, reflecting differing degrees to which the regional sampling domains are affected by melt. In some regions, including the Canadian Arctic, Alaska, Canadian Sub-Arctic and Ny-Ålesund, the differences between IS and ES scenarios are very small. In Greenland, however, and to a lesser extent Tromsø and the Arctic Ocean, there are noticeably higher modeled BC-in-snow concentrations in the IS scenario. To highlight the role of snowmelt in modulating the importance of these parameters, we plotted the histogram of the months when the samples were collected and the monthly mean snowmelt rate averaged over grid cells matching the observations in the different regions (Fig. 12). In regions that show no significant difference between IS and ES scenarios, there were few samples collected during times of large snowmelt. For example, the Ny-Ålesund samples were collected during March-May, before the July peak in model snowmelt rate, meaning the sub-sampled model domain is largely unaffected by melt. Most of the Greenland samples were collected at lower elevations during July and August, however, coincident with peak melt rates in the matching model domain (Fig. 12). About $43 \%$ of the sampling space coincides with the top model snow layer, and over $70 \%$ of it coincides with the top two model layers, where simulated concentrations are sensitive to the scavenging parameter during conditions of melt. Because much of the sampling space does not coincide with strong melt, however, the melt scavenging coefficients have only a second-order impact on the Arctic-wide model-measurement evaluation.

\section{BC-in-snow radiative effect}

Figure 13 shows the annual mean surface radiative effects caused by BC in snow, as simulated with deposition fields from the phase I and phase II models. Regions with relatively large radiative effects are northern Europe, Russia and Greenland. The two primary factors influencing annual-mean radiative effect in different regions are the amount of $\mathrm{BC}$ in snow and the seasonal evolution of snow cover fraction. For example, perennial snow cover in Greenland enables large forcing in this region despite relatively small $\mathrm{BC}$ concentrations. Persistence of cryospheric cover through summer is especially important because it maximizes the amount of insolation incident on impurity-laden snow and ice. The relatively small BC-in-snow radiative effects in central Greenland are caused by the small BC deposition fluxes in this area (Figs. 7 and 8) as well as little surface BC accumulation due to low snowmelt rate associated with high altitude and low temperature. Arctic annual mean BC in snow radiative effects for both phases and both sets of meltwater scavenging coefficients are shown in Table 4. With inefficient 

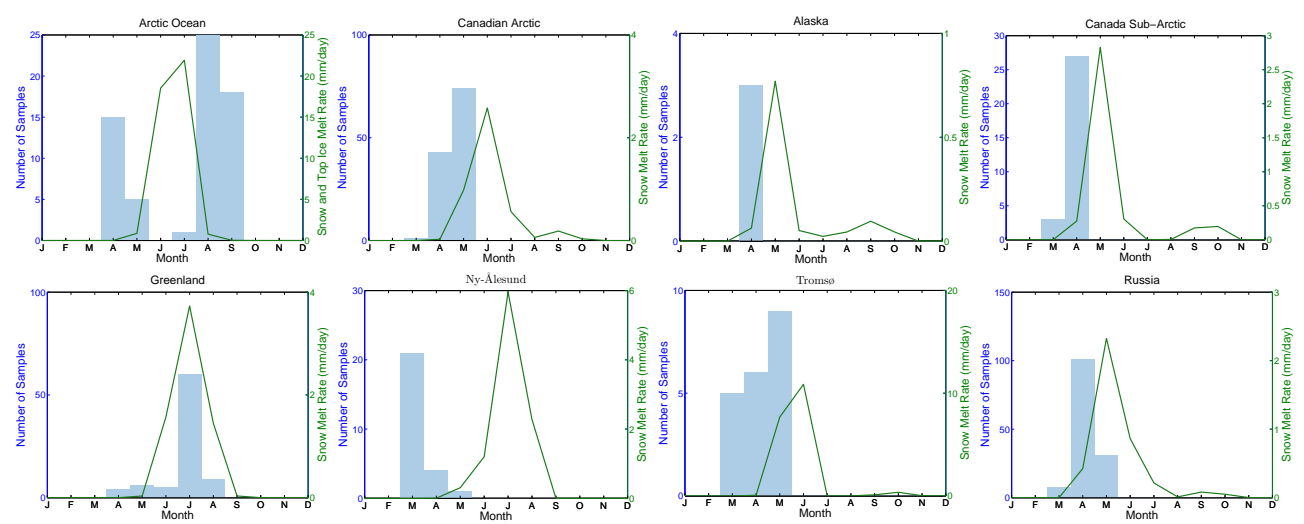

Fig. 12. Histogram of the months when the samples are collected in each region (plotted against left axis) and seasonal cycle of snow and ice melt rates (plotted against right axis). The melt rates are averaged only over grid cells containing observations within each region.
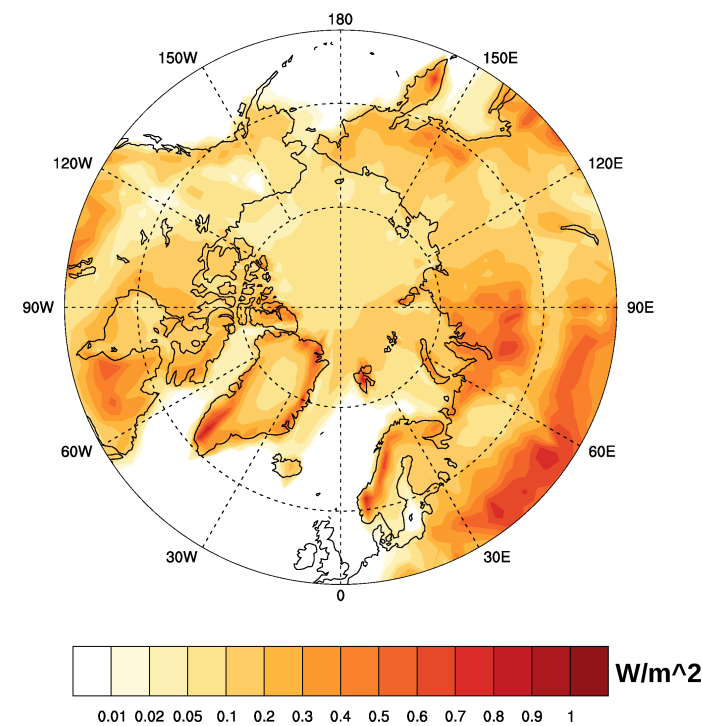
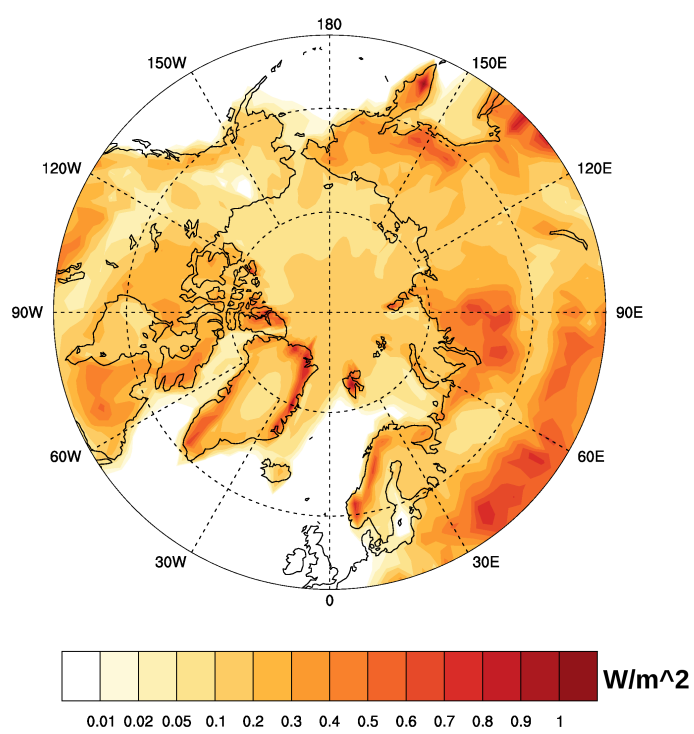

Fig. 13. Annual mean BC-in-snow radiative effects averaged across phase I (left panel) and phase II (right panel) models with inefficient meltwater scavenging.

scavenging, the modeled Arctic radiative effects for phase I models range from $0.07 \mathrm{~W} \mathrm{~m}^{-2}$ to $0.25 \mathrm{~W} \mathrm{~m}^{-2}$, and range from $0.06 \mathrm{~W} \mathrm{~m}^{-2}$ to $0.28 \mathrm{~W} \mathrm{~m}^{-2}$ for phase II models. With efficient scavenging, the radiative effects are slightly smaller, ranging from $0.06-0.21 \mathrm{~W} \mathrm{~m}^{-2}$ and $0.05-0.24 \mathrm{~W} \mathrm{~m}^{-2}$, respectively, for phase I and phase II models.

The multi-model mean $\mathrm{BC}$-in-snow radiative effect averaged over the Arctic (here, $60-90^{\circ} \mathrm{N}$ ) is $0.15 \mathrm{~W} \mathrm{~m}^{-2}$ and $0.18 \mathrm{~W} \mathrm{~m}^{-2}$ for phase I and phase II models, respectively, with inefficient meltwater scavenging. Model biases in BC concentrations in snow may also translate into biases in Arctic-mean radiative effect. Here we used the ratio between simulated and observed BC concentrations in different regions of the Arctic to derive observationally constrained forcings. In doing so, we assume a linear relationship between the near surface BC-in-snow concentration and radia- tive effect, which is a reasonable assumption for small perturbations about low BC concentrations (e.g., Flanner et al., 2007), such as those found in most of the Arctic. We divided the Arctic into 6 regions (Europe, Russia, Alaska, Canada, Greenland and the Arctic Ocean) and scaled the modeled radiative effects in each region by the ratio of observed-tomodeled $\mathrm{BC}$ concentrations in the sampling domain within each region. For each of the five land-based regions, the radiative effect is simulated with CLM, whereas radiative effect within the Arctic Ocean is simulated with CICE. Using this correction technique, we calculated an Arctic-mean BC-in-snow radiative effect of $0.17 \mathrm{~W} \mathrm{~m}^{-2}$ for the combined phase I and phase II ensembles. This approach has the advantage of accounting for model performance in different regions of the Arctic, but is only useful to the extent that model 
performance over the sampling domain is representative of model performance over each region as a whole.

\section{Conclusions}

We have used black carbon (BC) deposition fields produced from 25 global aerosol models to simulate vertically resolved $\mathrm{BC}$ concentrations in snow and sea ice with offline components of the Community Earth System Model. This exercise has enabled us to explore inter-model variability in Arctic $\mathrm{BC}$ deposition, evaluate model $\mathrm{BC}$ fields against a comprehensive field survey of $\mathrm{BC}$ measurements in Arctic snow (Doherty et al., 2010), and develop an observationally constrained estimate of Arctic radiative effects from BC in snow and sea ice. Though model mean BC concentrations in snow, averaged over the measurement domain, are generally close to the observational means, correlation coefficients between simulated and observed values are low, and variability among models is large. Models tend to underestimate BC amounts in snow in the Russian Arctic and northern Norway, while overestimating BC elsewhere in the Arctic. On average, however, phase I and phase II multimodel mean BC-in-snow concentrations are only $4.4 \mathrm{ng} \mathrm{g}^{-1}$ lower and $4.1 \mathrm{ng} \mathrm{g}^{-1}$ higher, respectively, than the observational mean of $19.2 \mathrm{ng} \mathrm{g}^{-1}$. Analysis shows that model aerosol transport and removal processes are the main factors influencing model-measurement evaluations, rather than the efficiency of particle removal with snowmelt water or variability in emissions applied within the models. Model residence times of $\mathrm{BC}$ in the Arctic atmosphere range from 3.7 to 23.2 days, much larger than the range in global residence times, indicating large model variability in local deposition efficiency. Multi-model means (ranges) of Arctic $\left(60-90^{\circ} \mathrm{N}\right)$ annual-mean radiative effects from $\mathrm{BC}$ in snow are $0.15(0.07-0.25) \mathrm{W} \mathrm{m}^{-2}$ and $0.18(0.06-0.28) \mathrm{W} \mathrm{m}^{-2}$ in phase I and phase II models, respectively. After correcting these estimates for biases in different regions of the Arctic, the mean Arctic radiative effects become $0.17 \mathrm{~W} \mathrm{~m}^{-2}$ for the combined phase I and phase II ensembles.

Acknowledgements. This research was partially supported by NSF ATM-0852775 and ARC-1023387. N. Bellouin was supported by the Joint DECC/Defra Met Office Hadley Centre Climate Programme (GA01101). S. Ghan and X. Liu were supported by the US Department of Energy, Office of Science, Scientific Discoveries through Advanced Computing program. The Pacific Northwest National Laboratory (PNNL) is operated for the DOE by Battelle Memorial Institute under contract DE-AC06-76RLO 1830. T. Iversen, A. Kirkevåg and $\varnothing$. Seland have been funded by the Research Council of Norway through the RegClim, NorClim, EarthClim (207711/E10) and NOTUR/NorStore projects, by the Norwegian Space Centre through PM-VRAE, and by the EU projects PEGASOS and ACCESS. R. B. Skeie has been funded by the Norwegian Research Council through the project SLAC (Short Lived Atmospheric Components) and the EU project ECLIPSE.
P. Stier acknowledges support from the UK Natural Environment Research Council project AEROS [NE/G006148/1]. K. Zhang was supported by funding from the Max Planck Society.

Edited by: P. Quinn

\section{References}

Aan de Brugh, J. M. J., Schaap, M., Vignati, E., Dentener, F., Kahnert, M., Sofiev, M., Huijnen, V., and Krol, M. C.: The European aerosol budget in 2006, Atmos. Chem. Phys., 11, 1117-1139, doi:10.5194/acp-11-1117-2011, 2011.

Ackermann, I. J., Hass, H., Memmesheimer, M., Ebel, A., Binkowski, F. S., and Shankar, U.: Modal aerosol dynamics model for Europe: development and first applications, Atmos. Environ., 32, 2981-2999, doi:10.1016/S1352-2310(98)00006-5, 1998.

Barth, M. C., Rasch, P., Kiehl, J. T., Benkovitz, C. M., and Schwartz, S. E.: Sulfur chemistry in the National Center for Atmospheric Research Community Climate Model: Description, evaluation, features, and sensitivity to aqueous chemistry, J. Geophys. Res., 105, 1387-1415, doi:10.1029/1999JD900773, 2000.

Bauer, S. E. and Koch, D.: Impact of heterogeneous sulfate formation at mineral dust surfaces on aerosol loads and radiative forcing in the Goddard Institute for Space Studies general circulation model, J. Geophys. Res., 110, D17202, doi:10.1029/2005JD005870, 2005.

Bauer, S. E., Koch, D., Unger, N., Metzger, S. M., Shindell, D. T., and Streets, D. G.: Nitrate aerosols today and in 2030: a global simulation including aerosols and tropospheric ozone, Atmos. Chem. Phys., 7, 5043-5059, doi:10.5194/acp-7-5043-2007, 2007.

Bauer, S. E., Wright, D. L., Koch, D., Lewis, E. R., McGraw, R., Chang, L.-S., Schwartz, S. E., and Ruedy, R.: MATRIX (Multiconfiguration Aerosol TRacker of mIXing state): an aerosol microphysical module for global atmospheric models, Atmos. Chem. Phys., 8, 6003-6035, doi:10.5194/acp-8-60032008, 2008.

Bauer, S. E., Menon, S., Koch, D., Bond, T. C., and Tsigaridis, K.: A global modeling study on carbonaceous aerosol microphysical characteristics and radiative effects, Atmos. Chem. Phys., 10, 7439-7456, doi:10.5194/acp-10-7439-2010, 2010.

Bellouin, N., Rae, J., Jones, A., Johnson, C., Haywood, J., and Boucher, O.: Aerosol forcing in the Climate Model Intercomparison Project (CMIP5) simulations by HadGEM2-ES and the role of ammonium nitrate, J. Geophys. Res., 116, D20206, doi:10.1029/2011JD016074, 2011.

Berglen, T. F., Berntsen, T. K., Isaksen, I. S. A., and Sundet, J. K.: A global model of the coupled sulfur/oxidant chemistry in the troposphere: The sulfur cycle, J. Geophys. Res., 109, D19310, doi:10.1029/2003JD003948, 2004.

Bian, H., Chin, M., Rodriguez, J. M., Yu, H., Penner, J. E., and Strahan, S.: Sensitivity of aerosol optical thickness and aerosol direct radiative effect to relative humidity, Atmos. Chem. Phys., 9, 2375-2386, doi:10.5194/acp-9-2375-2009, 2009.

Bond, T. C., Bhardwaj, E., Dong, R., Jogani, R., Jung, S., Roden, C., Streets, D. G., and Trautmann, N. M.: Historical emissions of black and organic carbon aerosol from energy-related 
combustion, 1850-2000, Global Biogeochem. Cy., 21, GB2018, doi:10.1029/2006GB002840, 2007.

Bond, T. C., Doherty, S. J., Fahey, D. W., Forster, P. M., Berntsen, T., DeAngelo, B. J., Flanner, M. G., Ghan, S., Kärcher, B., Koch, D., Kinne, S., Kondo, Y., Quinn, P. K., Sarofim, M. C., Schultz, M. G., Schulz, M., Venkataraman, C., Zhang, H., Zhang, S., Bellouin, N., Guttikunda, S. K., Hopke, P. K., Jacobson, M. Z., Kaiser, J. W., Klimont, Z., Lohmann, U., Schwarz, J. P., Shindell, D., Storelvmo, T., Warren, S. G., and Zender, C. S.: Bounding the role of black carbon in the climate system: A scientific assessment, J. Geophys. Res.-Atmos., 118, 5380-5552, doi:10.1002/jgrd.50171, 2013.

Bourgeois, Q. and Bey, I.: Pollution transport efficiency toward the Arctic: Sensitivity to aerosol scavenging and source regions, J. Geophys. Res.-Atmos., 116, D08213, doi:10.1029/2010JD015096, 2011.

Briegleb, B. P. and Light, B.: A Delta-Eddington multiple scattering parameterization for solar radiation in the sea ice component of the Community Climate System Model, Tech. Rep. NCAR/TN472+STR, National Center for Atmospheric Research, 2007.

Browse, J., Carslaw, K. S., Arnold, S. R., Pringle, K., and Boucher, O.: The scavenging processes controlling the seasonal cycle in Arctic sulphate and black carbon aerosol, Atmos. Chem. Phys., 12, 6775-6798, doi:10.5194/acp-12-6775-2012, 2012.

Mian Chin, Diehl, T., Dubovik, O., Eck, T. F., Holben, B. N., Sinyuk, A., and Streets, D. G.: Light absorption by pollution, dust, and biomass burning aerosols: a global model study and evaluation with AERONET measurements, Ann. Geophys., 27, 3439-3464, doi:10.5194/angeo-27-3439-2009, 2009.

Conway, H., Gades, A., and Raymond, C. F.: Albedo of dirty snow during conditions of melt, Water Resour. Res., 32, 1713-1718, doi:10.1029/96WR00712, 1996.

de Meij, A., Krol, M., Dentener, F., Vignati, E., Cuvelier, C., and Thunis, P.: The sensitivity of aerosol in Europe to two different emission inventories and temporal distribution of emissions, Atmos. Chem. Phys., 6, 4287-4309, doi:10.5194/acp-6-4287-2006, 2006.

Dentener, F., Kinne, S., Bond, T., Boucher, O., Cofala, J., Generoso, S., Ginoux, P., Gong, S., Hoelzemann, J. J., Ito, A., Marelli, L., Penner, J. E., Putaud, J.-P., Textor, C., Schulz, M., van der Werf, G. R., and Wilson, J.: Emissions of primary aerosol and precursor gases in the years 2000 and 1750 prescribed data-sets for AeroCom, Atmos. Chem. Phys., 6, 4321-4344, doi:10.5194/acp-64321-2006, 2006.

Doherty, S. J., Warren, S. G., Grenfell, T. C., Clarke, A. D., and Brandt, R. E.: Light-absorbing impurities in Arctic snow, Atmos. Chem. Phys., 10, 11647-11680, doi:10.5194/acp-1011647-2010, 2010.

Doherty, S. J., Grenfell, T. C., Forsström, S., Hegg, D. L., Brandt, R. E., and Warren, S. G.: Observed vertical redistribution of black carbon and other insoluble light-absorbing particles in melting snow, J. Geophys. Res.-Atmos., 118, 5553-5569, doi:10.1002/jgrd.50235, 2013.

Dou, T., Xiao, C., Shindell, D. T., Liu, J., Eleftheriadis, K., Ming, J., and Qin, D.: The distribution of snow black carbon observed in the Arctic and compared to the GISS-PUCCINI model, Atmos. Chem. Phys., 12, 7995-8007, doi:10.5194/acp-12-79952012, 2012.
Flanner, M. G., Zender, C. S., Randerson, J. T., and Rasch, P. J.: Present day climate forcing and response from black carbon in snow, J. Geophys. Res., 112, D11202, doi:10.1029/2006JD008003, 2007.

Flanner, M. G., Zender, C. S., Hess, P. G., Mahowald, N. M., Painter, T. H., Ramanathan, V., and Rasch, P. J.: Springtime warming and reduced snow cover from carbonaceous particles, Atmos. Chem. Phys., 9, 2481-2497, doi:10.5194/acp-9-24812009, 2009.

Garrett, T. J., Zhao, C., and Novelli, P. C.: Assessing the relative contributions of transport efficiency and scavenging to seasonal variability in Arctic aerosol, Tellus B, 62, 190-196, doi:10.1111/j.1600-0889.2010.00453.x, 2010.

Ghan, S. J., Liu, X., Easter, R. C., Zaveri, R., Rasch, P. J., and Yoon, J.-H.: Toward a Minimal Representation of Aerosols in Climate Models: Comparative Decomposition of Aerosol Direct, Semidirect, and Indirect Radiative Forcing, J. Climate, 25, 6461-6476, doi:10.1175/JCLI-D-11-00650.1, 2012.

Grenfell, T. C., Doherty, S. J., Clarke, A. D., and Warren, S. G.: Light absorption from particulate impurities in snow and ice determined by spectrophotometric analysis of filters, Appl. Optics, 50, 2037-2048, doi:10.1364/AO.50.002037, 2011.

Grini, A., Myhre, G., Sundet, J. K., and Isaksen, I. S. A.: Modeling the Annual Cycle of Sea Salt in the Global 3D Model Oslo CTM2: Concentrations, Fluxes, and Radiative Impact, J. Climate, 15, 1717-1730, doi:10.1175/15200442(2002)015<1717:MTACOS>2.0.CO;2, 2002.

Grini, A., Myhre, G., Zender, C. S., and Isaksen, I. S. A.: Model simulations of dust sources and transport in the global atmosphere: Effects of soil erodibility and wind speed variability, J. Geophys. Res., 110, D02205, doi:10.1029/2004JD005037, 2005.

Hansen, J. and Nazarenko, L.: Soot climate forcing via snow and ice albedos, P. Natl. Acad. Sci. USA, 101, 423-428, doi:10.1073/pnas.2237157100, 2004.

Holland, M., Bailey, D. A., Briegleb, B. P., Light, B., and Hunke, E.: Improved sea ice shortwave radiation physics in CCSM4: The impact of melt ponds and aerosols on Arctic sea ice, J. Climate, 25, 1413-1430, doi:10.1175/JCLI-D-11-00078.1, 2012.

Iversen, T. and Seland, Ø.: A scheme for process-tagged SO4 and $\mathrm{BC}$ aerosols in NCAR CCM3: Validation and sensitivity to cloud processes, J. Geophys. Res., 107, AAC 4-1-AAC 4-30, doi:10.1029/2001JD000885, 2002.

Jacobson, M. Z.: Climate response of fossil fuel and biofuel soot, accounting for soot's feedback to snow and sea ice albedo and emissivity, J. Geophys. Res., 109, D21201, doi:10.1029/2004JD004945, 2004.

Kinne, S., Schulz, M., Textor, C., Guibert, S., Balkanski, Y., Bauer, S. E., Berntsen, T., Berglen, T. F., Boucher, O., Chin, M., Collins, W., Dentener, F., Diehl, T., Easter, R., Feichter, J., Fillmore, D., Ghan, S., Ginoux, P., Gong, S., Grini, A., Hendricks, J., Herzog, M., Horowitz, L., Isaksen, I., Iversen, T., Kirkevåg, A., Kloster, S., Koch, D., Kristjansson, J. E., Krol, M., Lauer, A., Lamarque, J. F., Lesins, G., Liu, X., Lohmann, U., Montanaro, V., Myhre, G., Penner, J., Pitari, G., Reddy, S., Seland, O., Stier, P., Takemura, T., and Tie, X.: An AeroCom initial assessment - optical properties in aerosol component modules of global models, Atmos. Chem. Phys., 6, 1815-1834, doi:10.5194/acp-6-1815-2006, 2006. 
Kirkevåg, A. and Iversen, T.: Global direct radiative forcing by process-parameterized aerosol optical properties, J. Geophys. Res., 107, AAC 6-1-AAC 6-16, doi:10.1029/2001JD000886, 2002.

Kirkevåg, A., Iversen, T., Seland, Ø., Hoose, C., Kristjánsson, J. E., Struthers, H., Ekman, A. M. L., Ghan, S., Griesfeller, J., Nilsson, E. D., and Schulz, M.: Aerosol-climate interactions in the Norwegian Earth System Model - NorESM1-M, Geosci. Model Dev., 6, 207-244, doi:10.5194/gmd-6-207-2013, 2013.

Kistler, R., Kalnay, E., Collins, W., Saha, S., White, G., Woollen, J., Chelliah, M., Ebisuzaki, W., Kanamitsu, M., Kousky, V., van den Dool, H., Jenne, R., and Fiorino, M.: The NCEP-NCAR 50Year Reanalysis: Monthly Means CD-ROM and Documentation, B. Am. Meteorol. Soc., 82, 247-267, doi:10.1175/15200477(2001)082<0247:TNNYRM>2.3.CO;2, 1999.

Koch, D.: Transport and direct radiative forcing of carbonaceous and sulfate aerosols in the GISS GCM, J. Geophys. Res., 106, 20311-20332, doi:10.1029/2001JD900038, 2001.

Koch, D. and Del Genio, A. D.: Black carbon semi-direct effects on cloud cover: review and synthesis, Atmos. Chem. Phys., 10, 7685-7696, doi:10.5194/acp-10-7685-2010, 2010.

Koch, D. and Hansen, J.: Distant origins of Arctic black carbon: A Goddard Institute for Space Studies ModelE experiment, J. Geophys. Res., 110, D04204, doi:10.1029/2004JD005296, 2005.

Koch, D., Schmidt, G. A., and Field, C.: Sulfur, sea salt and radionuclide aerosols in GISS ModelE, J. Geophys. Res., 111, D06206, doi:10.1029/2004JD005550, 2006.

Koch, D., Bond, T. C., Streets, D., Unger, N., and van der Werf, G. R.: Global impacts of aerosols from particular source regions and sectors, J. Geophys. Res., 112, D02205, doi:10.1029/2005JD007024, 2007.

Koch, D., Schulz, M., Kinne, S., McNaughton, C., Spackman, J. R., Balkanski, Y., Bauer, S., Berntsen, T., Bond, T. C., Boucher, O., Chin, M., Clarke, A., De Luca, N., Dentener, F., Diehl, T., Dubovik, O., Easter, R., Fahey, D. W., Feichter, J., Fillmore, D., Freitag, S., Ghan, S., Ginoux, P., Gong, S., Horowitz, L., Iversen, T., Kirkevåg, A., Klimont, Z., Kondo, Y., Krol, M., Liu, X., Miller, R., Montanaro, V., Moteki, N., Myhre, G., Penner, J. E., Perlwitz, J., Pitari, G., Reddy, S., Sahu, L., Sakamoto, H., Schuster, G., Schwarz, J. P., Seland, Ø., Stier, P., Takegawa, N., Takemura, T., Textor, C., van Aardenne, J. A., and Zhao, Y.: Evaluation of black carbon estimations in global aerosol models, Atmos. Chem. Phys., 9, 9001-9026, doi:10.5194/acp-9-9001-2009, 2009.

Koch, D., Balkanski, Y., Bauer, S. E., Easter, R. C., Ferrachat, S., Ghan, S. J., Hoose, C., Iversen, T., Kirkevåg, A., Kristjansson, J. E., Liu, X., Lohmann, U., Menon, S., Quaas, J., Schulz, M., Seland, Ø., Takemura, T., and Yan, N.: Soot microphysical effects on liquid clouds, a multi-model investigation, Atmos. Chem. Phys., 11, 1051-1064, doi:10.5194/acp-11-1051-2011, 2011.

Koffi, B., Schulz, M., Bréon, F.-M., Griesfeller, J., Winker, D., Balkanski, Y., Bauer, S., Chin, T. B. M., Collins, W. D., Dentener, F., Diehl, T., Easter, R., Ghan, S., Ginoux, P., Gong, S., Horowitz, L. W., Iversen, T., Kirkevåg, A., Koch, D., Krol, M., Myhre, G., Stier, P., and Takemura, T.: Application of the CALIOP layer product to evaluate the vertical distribution of aerosols estimated by global models: AeroCom phase I results, J. Geophys. Res., 117, D10201, doi:10.1029/2011JD016858, 2012.
Krol, M., Houweling, S., Bregman, B., van den Broek, M., Segers, A., van Velthoven, P., Peters, W., Dentener, F., and Bergamaschi, P.: The two-way nested global chemistry-transport zoom model TM5: algorithm and applications, Atmos. Chem. Phys., 5, 417432, doi:10.5194/acp-5-417-2005, 2005.

Lawrence, D., Oleson, K., Flanner, M., Thorton, P., Swenson, S., Lawrence, P., Zeng, X., Yang, Z.-L., Levis, S., Skaguchi, K., Bonan, G., and Slater, A.: Parameterization Improvements and Functional and Structural Advances in Version 4 of the Community Land Model, Journal of Advances in Modeling Earth Systems, 3, M03001, doi:10.1029/JAMES.2011.3.45, 2011.

Lee, L. A., Pringle, K. J., Reddington, C. L., Mann, G. W., Stier, P., Spracklen, D. V., Pierce, J. R., and Carslaw, K. S.: The magnitude and causes of uncertainty in global model simulations of cloud condensation nuclei, Atmos. Chem. Phys., 13, 8879-8914, doi:10.5194/acp-13-8879-2013, 2013a.

Lee, Y. H., Lamarque, J.-F., Flanner, M. G., Jiao, C., Shindell, D. T., Berntsen, T., Bisiaux, M. M., Cao, J., Collins, W. J., Curran, M., Edwards, R., Faluvegi, G., Ghan, S., Horowitz, L. W., McConnell, J. R., Ming, J., Myhre, G., Nagashima, T., Naik, V., Rumbold, S. T., Skeie, R. B., Sudo, K., Takemura, T., Thevenon, F., Xu, B., and Yoon, J.-H.: Evaluation of preindustrial to presentday black carbon and its albedo forcing from Atmospheric Chemistry and Climate Model Intercomparison Project (ACCMIP), Atmos. Chem. Phys., 13, 2607-2634, doi:10.5194/acp13-2607-2013, 2013b.

Liu, J., Fan, S., Horowitz, L. W., and Levy, H.: Evaluation of factors controlling long-range transport of black carbon to the Arctic, J. Geophys. Res.-Atmos., 116, D04307, doi:10.1029/2010JD015145, 2011.

Liu, X. and Penner, J. E.: Effect of Mount Pinatubo H2SO4/H2O aerosol on ice nucleation in the upper troposphere using a global chemistry and transport model, J. Geophys. Res.-Atmos., 107, AAC 2-1-AAC 2-18, doi:10.1029/2001JD000455, 2002.

Liu, X., Easter, R. C., Ghan, S. J., Zaveri, R., Rasch, P., Shi, X., Lamarque, J.-F., Gettelman, A., Morrison, H., Vitt, F., Conley, A., Park, S., Neale, R., Hannay, C., Ekman, A. M. L., Hess, P., Mahowald, N., Collins, W., Iacono, M. J., Bretherton, C. S., Flanner, M. G., and Mitchell, D.: Toward a minimal representation of aerosols in climate models: description and evaluation in the Community Atmosphere Model CAM5, Geosci. Model Dev., 5, 709-739, doi:10.5194/gmd-5-709-2012, 2012.

Lund, M. T. and Berntsen, T.: Parameterization of black carbon aging in the OsloCTM2 and implications for regional transport to the Arctic, Atmos. Chem. Phys., 12, 6999-7014, doi:10.5194/acp-12-6999-2012, 2012.

McConnell, J. R., Edwards, R., Kok, G. L., Flanner, M. G., Zender, C. S., Saltzman, E. S., Banta, J. R., Pasteris, D. R., Carter, M. M., and Kahl, J. D. W.: 20th-Century Industrial Black Carbon Emissions Altered Arctic Climate Forcing, Science, 317, 1381-1384, doi:10.1126/science.1144856, 2007.

Menon, S., Hansen, J., Nazarenko, L., and Luo, Y.: Climate Effects of Black Carbon Aerosols in China and India, Science, 297, 2250-2253, doi:10.1126/science.1075159, 2002.

Myhre, G., Bellouin, N., Berglen, T. F., Berntsen, T. K., Boucher, O., Grini, A., Isaksen, I. S. A., Johnsrud, M., Mishchenko, M. I., Stordal, F., and Tanré, D.: Comparison of the radiative properties and direct radiative effect of aerosols from a global aerosol 
model and remote sensing data over ocean, Tellus B, 59, 115129, doi:10.1111/j.1600-0889.2006.00226.x, 2007.

Myhre, G., Berglen, T. F., Johnsrud, M., Hoyle, C. R., Berntsen, T. K., Christopher, S. A., Fahey, D. W., Isaksen, I. S. A., Jones, T. A., Kahn, R. A., Loeb, N., Quinn, P., Remer, L., Schwarz, J. P., and Yttri, K. E.: Modelled radiative forcing of the direct aerosol effect with multi-observation evaluation, Atmos. Chem. Phys., 9, 1365-1392, doi:10.5194/acp-9-1365-2009, 2009.

Myhre, G., Samset, B. H., Schulz, M., Balkanski, Y., Bauer, S., Berntsen, T. K., Bian, H., Bellouin, N., Chin, M., Diehl, T., Easter, R. C., Feichter, J., Ghan, S. J., Hauglustaine, D., Iversen, T., Kinne, S., Kirkevåg, A., Lamarque, J.-F., Lin, G., Liu, X., Lund, M. T., Luo, G., Ma, X., van Noije, T., Penner, J. E., Rasch, P. J., Ruiz, A., Seland, Ø., Skeie, R. B., Stier, P., Takemura, T., Tsigaridis, K., Wang, P., Wang, Z., Xu, L., Yu, H., Yu, F., Yoon, J.-H., Zhang, K., Zhang, H., and Zhou, C.: Radiative forcing of the direct aerosol effect from AeroCom Phase II simulations, Atmos. Chem. Phys., 13, 1853-1877, doi:10.5194/acp-13-18532013, 2013.

Pitari, G., Mancini, E., Rizi, V., and Shindell, D. T.: Impact of Future Climate and Emission Changes on Stratospheric Aerosols and Ozone, J. Atmos. Sci., 59, 414-440, doi:10.1175/15200469(2002)059<0414:IOFCAE>2.0.CO;2, 2002.

Pitari, G., Iachetti, D., Mancini, E., Montanaro, V., De Luca, N., Marizy, C., Dessens, O., Rogers, H., Pyle, J., Grewe, V., Stenke, A., and Søvde, O. A.: Radiative forcing from particle emissions by future supersonic aircraft, Atmos. Chem. Phys., 8, 40694084, doi:10.5194/acp-8-4069-2008, 2008.

Rasch, P. J., Feichter, J., Law, K., Mahowald, N., Penner, J., Benkovitz, C., Genthon, C., Giannakopoulos, C., Kasibhatla, P., Koch, D., Levy, H., Maki, T., Prather, M., Roberts, D. L., Roelofs, G.-J., Stevenson, D., Stockwell, Z., Taguchi, S., Kritz, M., Chipperfield, M., Baldocchi, D., Mcmurry, P., Barrie, L., Balkanski, Y., Chatfield, R., Kjellstrom, E., Lawrence, M., Lee, H. N., Lelieveld, J., Noone, K. J., Seinfeld, J., Stenchikov, G., Schwartz, S., Walcek, C., and Williamson, D.: A comparison of scavenging and deposition processes in global models: results from the WCRP Cambridge Workshop of 1995, Tellus B, 52, 1025-1056, doi:10.1034/j.1600-0889.2000.00980.x, 2000.

Rasch, P. J., Collins, W. D., and Eaton, B. E.: Understanding the Indian Ocean Experiment (INDOEX) aerosol distributions with an aerosol assimilation, J. Geophys. Res., 106, 7337-7355, doi:10.1029/2000JD900508, 2001.

Reddy, M. S. and Boucher, O.: A study of the global cycle of carbonaceous aerosols in the LMDZT general circulation model, J. Geophys. Res.-Atmos., 109, D14202, doi:10.1029/2003JD004048, 2004.

Samset, B. H., Myhre, G., Schulz, M., Balkanski, Y., Bauer, S., Berntsen, T. K., Bian, H., Bellouin, N., Diehl, T., Easter, R. C., Ghan, S. J., Iversen, T., Kinne, S., Kirkevåg, A., Lamarque, J.F., Lin, G., Liu, X., Penner, J. E., Seland, Ø., Skeie, R. B., Stier, P., Takemura, T., Tsigaridis, K., and Zhang, K.: Black carbon vertical profiles strongly affect its radiative forcing uncertainty, Atmos. Chem. Phys., 13, 2423-2434, doi:10.5194/acp-13-24232013, 2013.

Schulz, M., Textor, C., Kinne, S., Balkanski, Y., Bauer, S., Berntsen, T., Berglen, T., Boucher, O., Dentener, F., Guibert, S., Isaksen, I. S. A., Iversen, T., Koch, D., Kirkevåg, A., Liu, X., Montanaro, V., Myhre, G., Penner, J. E., Pitari, G., Reddy, S., Seland,
Ø., Stier, P., and Takemura, T.: Radiative forcing by aerosols as derived from the AeroCom present-day and pre-industrial simulations, Atmos. Chem. Phys., 6, 5225-5246, doi:10.5194/acp-65225-2006, 2006.

Schulz, M., Chin, M., and Kinne, S.: The Aerosol Model Comparison Project, AeroCom, Phase II: Clearing Up Diversity, IGAC Newsletter, 2009.

Schwarz, J. P., Spackman, J. R., Gao, R. S., Watts, L. A., Stier, P., Schulz, M., Davis, S. M., Wofsy, S. C., and Fahey, D. W.: Global-scale black carbon profiles observed in the remote atmosphere and compared to models, Geophys. Res. Lett., 37, L18812, doi:10.1029/2010GL044372, 2010.

Seland, Ø., Iversen, T., Kirkevåg, A., and Storelvmo, T.: Aerosolclimate interactions in the CAM-Oslo atmospheric GCM and investigation of associated basic shortcomings, Tellus A, 60, 459491, doi:10.1111/j.1600-0870.2008.00318.x, 2008.

Shindell, D. T., Chin, M., Dentener, F., Doherty, R. M., Faluvegi, G., Fiore, A. M., Hess, P., Koch, D. M., MacKenzie, I. A., Sanderson, M. G., Schultz, M. G., Schulz, M., Stevenson, D. S., Teich, H., Textor, C., Wild, O., Bergmann, D. J., Bey, I., Bian, H., Cuvelier, C., Duncan, B. N., Folberth, G., Horowitz, L. W., Jonson, J., Kaminski, J. W., Marmer, E., Park, R., Pringle, K. J., Schroeder, S., Szopa, S., Takemura, T., Zeng, G., Keating, T. J., and Zuber, A.: A multi-model assessment of pollution transport to the Arctic, Atmos. Chem. Phys., 8, 5353-5372, doi:10.5194/acp-85353-2008, 2008.

Shindell, D. T., Lamarque, J.-F., Schulz, M., Flanner, M., Jiao, C., Chin, M., Young, P. J., Lee, Y. H., Rotstayn, L., Mahowald, N., Milly, G., Faluvegi, G., Balkanski, Y., Collins, W. J., Conley, A. J., Dalsoren, S., Easter, R., Ghan, S., Horowitz, L., Liu, X., Myhre, G., Nagashima, T., Naik, V., Rumbold, S. T., Skeie, R., Sudo, K., Szopa, S., Takemura, T., Voulgarakis, A., Yoon, J.-H., and Lo, F.: Radiative forcing in the ACCMIP historical and future climate simulations, Atmos. Chem. Phys., 13, 2939-2974, doi:10.5194/acp-13-2939-2013, 2013.

Skeie, R. B., Berntsen, T., Myhre, G., Pedersen, C. A., Ström, J., Gerland, S., and Ogren, J. A.: Black carbon in the atmosphere and snow, from pre-industrial times until present, Atmos. Chem. Phys., 11, 6809-6836, doi:10.5194/acp-11-6809-2011, 2011a.

Skeie, R. B., Berntsen, T. K., Myhre, G., Tanaka, K., Kvalevåg, M. M., and Hoyle, C. R.: Anthropogenic radiative forcing time series from pre-industrial times until 2010, Atmos. Chem. Phys., 11, 11827-11857, doi:10.5194/acp-11-11827-2011, 2011 b.

Spracklen, D. V., Pringle, K. J., Carslaw, K. S., Chipperfield, M. P., and Mann, G. W.: A global off-line model of sizeresolved aerosol microphysics: I. Model development and prediction of aerosol properties, Atmos. Chem. Phys., 5, 22272252, doi:10.5194/acp-5-2227-2005, 2005.

Spracklen, D. V., Carslaw, K. S., Pöschl, U., Rap, A., and Forster, P. M.: Global cloud condensation nuclei influenced by carbonaceous combustion aerosol, Atmos. Chem. Phys., 11, 9067-9087, doi:10.5194/acp-11-9067-2011, 2011.

Sterle, K. M., McConnell, J. R., Dozier, J., Edwards, R., and Flanner, M. G.: Retention and radiative forcing of black carbon in eastern Sierra Nevada snow, The Cryosphere, 7, 365-374, doi:10.5194/tc-7-365-2013, 2013.

Stier, P., Feichter, J., Kinne, S., Kloster, S., Vignati, E., Wilson, J., Ganzeveld, L., Tegen, I., Werner, M., Balkanski, Y., Schulz, M., Boucher, O., Minikin, A., and Petzold, A.: The aerosol-climate 
model ECHAM5-HAM, Atmos. Chem. Phys., 5, 1125-1156, doi:10.5194/acp-5-1125-2005, 2005.

Stier, P., Seinfeld, J. H., Kinne, S., and Boucher, O.: Aerosol absorption and radiative forcing, Atmos. Chem. Phys., 7, 5237-5261, doi:10.5194/acp-7-5237-2007, 2007.

Stier, P., Schutgens, N. A. J., Bellouin, N., Bian, H., Boucher, O., Chin, M., Ghan, S., Huneeus, N., Kinne, S., Lin, G., Ma, X., Myhre, G., Penner, J. E., Randles, C. A., Samset, B., Schulz, M., Takemura, T., Yu, F., Yu, H., and Zhou, C.: Host model uncertainties in aerosol radiative forcing estimates: results from the AeroCom Prescribed intercomparison study, Atmos. Chem. Phys., 13, 3245-3270, doi:10.5194/acp-13-3245-2013, 2013.

Stohl, A.: Characteristics of atmospheric transport into the Arctic troposphere, J. Geophys. Res., 111, D11306, doi:10.1029/2005JD006888, 2006.

Stohl, A., Klimont, Z., Eckhardt, S., Kupiainen, K., Shevchenko, V. P., Kopeikin, V. M., and Novigatsky, A. N.: Black carbon in the Arctic: the underestimated role of gas flaring and residential combustion emissions, Atmos. Chem. Phys., 13, 8833-8855, doi:10.5194/acp-13-8833-2013, 2013.

Szopa, S., Balkanski, Y., Schulz, M., Bekki, S., Cugnet, D., Fortems-Cheiney, A., Turquety, S., Cozic, A., Déandreis, C., Hauglustaine, D., Idelkadi, A., Lathière, J., Lefevre, F., Marchand, M., Vuolo, R., Yan, N., and Dufresne, J.-L.: Aerosol and ozone changes as forcing for climate evolution between 1850 and 2100, Clim. Dynam., 40, 2223-2250, doi:10.1007/s00382-0121408-y, 2013.

Takemura, T., Nozawa, T., Emori, S., Nakajima, T. Y., and Nakajima, T.: Simulation of climate response to aerosol direct and indirect effects with aerosol transport-radiation model, J. Geophys. Res., 110, D02202, doi:10.1029/2004JD005029, 2005.

Takemura, T., Egashira, M., Matsuzawa, K., Ichijo, H., O'ishi, R., and Abe-Ouchi, A.: A simulation of the global distribution and radiative forcing of soil dust aerosols at the Last Glacial Maximum, Atmos. Chem. Phys., 9, 3061-3073, doi:10.5194/acp-93061-2009, 2009.

Textor, C., Schulz, M., Guibert, S., Kinne, S., Balkanski, Y., Bauer, S., Berntsen, T., Berglen, T., Boucher, O., Chin, M., Dentener, F., Diehl, T., Easter, R., Feichter, H., Fillmore, D., Ghan, S., Ginoux, P., Gong, S., Grini, A., Hendricks, J., Horowitz, L., Huang, P., Isaksen, I., Iversen, I., Kloster, S., Koch, D., Kirkevåg, A., Kristjansson, J. E., Krol, M., Lauer, A., Lamarque, J. F., Liu, X., Montanaro, V., Myhre, G., Penner, J., Pitari, G., Reddy, S., Seland, Ø., Stier, P., Takemura, T., and Tie, X.: Analysis and quantification of the diversities of aerosol life cycles within AeroCom, Atmos. Chem. Phys., 6, 1777-1813, doi:10.5194/acp-6-1777-2006, 2006.
Textor, C., Schulz, M., Guibert, S., Kinne, S., Balkanski, Y., Bauer, S., Berntsen, T., Berglen, T., Boucher, O., Chin, M., Dentener, F., Diehl, T., Feichter, J., Fillmore, D., Ginoux, P., Gong, S., Grini, A., Hendricks, J., Horowitz, L., Huang, P., Isaksen, I. S A., Iversen, T., Kloster, S., Koch, D., Kirkevåg, A., Kristjansson, J. E., Krol, M., Lauer, A., Lamarque, J. F., Liu, X., Montanaro, V., Myhre, G., Penner, J. E., Pitari, G., Reddy, M. S., Seland, Ø., Stier, P., Takemura, T., and Tie, X.: The effect of harmonized emissions on aerosol properties in global models an AeroCom experiment, Atmos. Chem. Phys., 7, 4489-4501, doi:10.5194/acp-7-4489-2007, 2007.

Vignati, E., Karl, M., Krol, M., Wilson, J., Stier, P., and Cavalli, F.: Sources of uncertainties in modelling black carbon at the global scale, Atmos. Chem. Phys., 10, 2595-2611, doi:10.5194/acp-102595-2010, 2010.

von Hardenberg, J., Vozella, L., Tomasi, C., Vitale, V., Lupi, A., Mazzola, M., van Noije, T. P. C., Strunk, A., and Provenzale, A.: Aerosol optical depth over the Arctic: a comparison of ECHAMHAM and TM5 with ground-based, satellite and reanalysis data, Atmos. Chem. Phys., 12, 6953-6967, doi:10.5194/acp-12-69532012, 2012.

Wang, H., Easter, R. C., Rasch, P. J., Wang, M., Liu, X., Ghan, S. J., Qian, Y., Yoon, J.-H., Ma, P.-L., and Vinoj, V.: Sensitivity of remote aerosol distributions to representation of cloud-aerosol interactions in a global climate model, Geosci. Model Dev., 6, 765-782, doi:10.5194/gmd-6-765-2013, 2013.

Xu, B., Cao, J., Joswiak, D. R., Liu, X., Zhao, H., and He, J.: Postdepositional enrichment of black soot in snow-pack and accelerated melting of Tibetan glaciers, Environ. Res. Lett., 7, 014022, doi:10.1088/1748-9326/7/1/014022, 2012.

Yun, Y. and Penner, J. E.: Global model comparison of heterogeneous ice nucleation parameterizations in mixed phase clouds, J. Geophys. Res.-Atmos., 117, D07203, doi:10.1029/2011JD016506, 2012.

Zhang, K., O’Donnell, D., Kazil, J., Stier, P., Kinne, S., Lohmann, U., Ferrachat, S., Croft, B., Quaas, J., Wan, H., Rast, S., and Feichter, J.: The global aerosol-climate model ECHAM-HAM, version 2: sensitivity to improvements in process representations, Atmos. Chem. Phys., 12, 8911-8949, doi:10.5194/acp-12-89112012, 2012. 